Provided for non-commercial research and education use. Not for reproduction, distribution or commercial use.

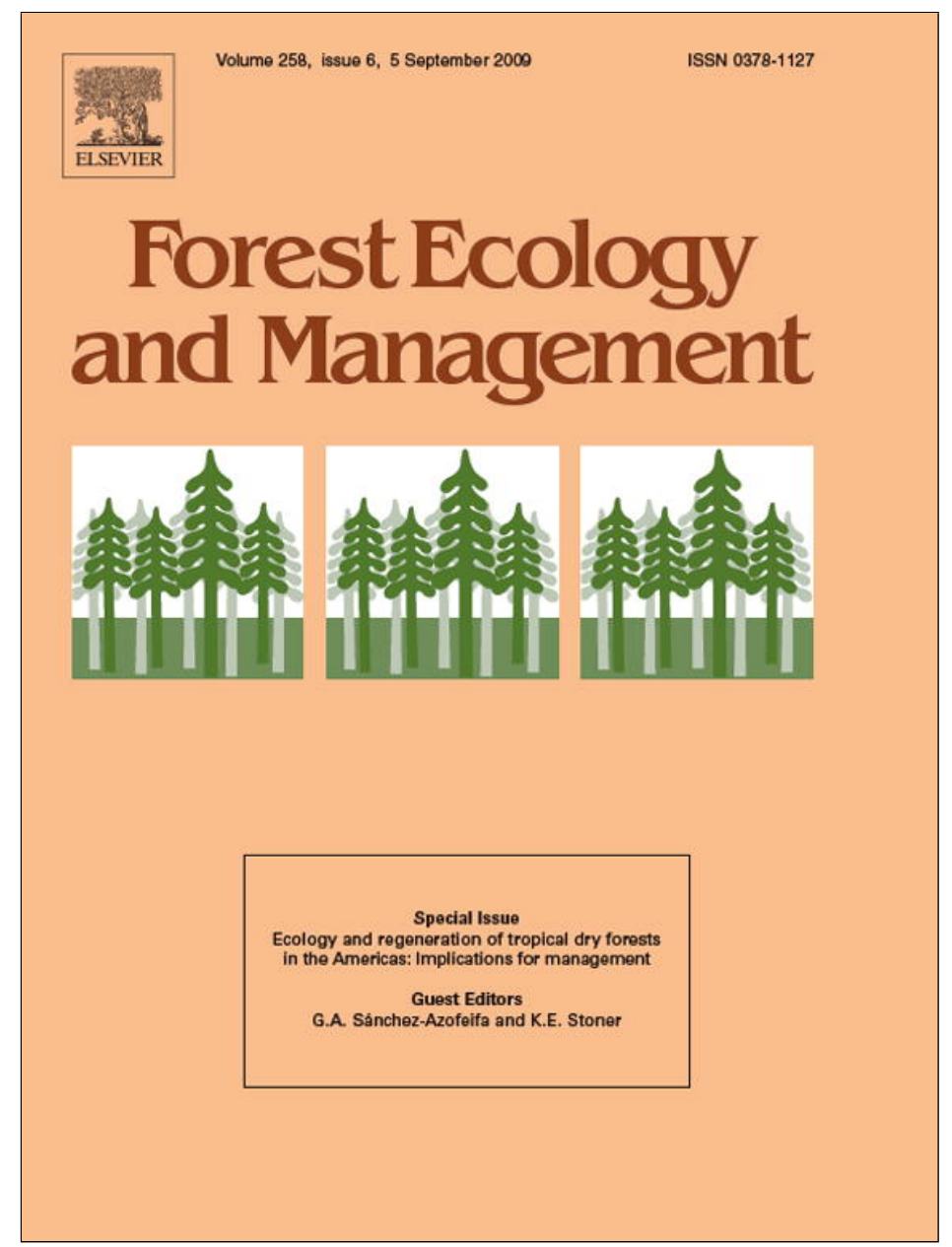

This article appeared in a journal published by Elsevier. The attached copy is furnished to the author for internal non-commercial research and education use, including for instruction at the authors institution and sharing with colleagues.

Other uses, including reproduction and distribution, or selling or licensing copies, or posting to personal, institutional or third party websites are prohibited.

In most cases authors are permitted to post their version of the article (e.g. in Word or Tex form) to their personal website or institutional repository. Authors requiring further information regarding Elsevier's archiving and manuscript policies are encouraged to visit:

http://www.elsevier.com/copyright 


\title{
Mammals of Cabo Blanco: History, diversity, and conservation after 45 years of regrowth of a Costa Rican dry forest
}

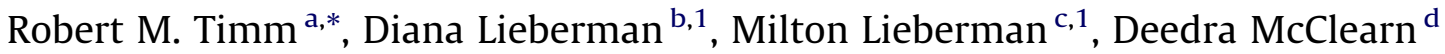 \\ ${ }^{a}$ Natural History Museum E Biodiversity Research Center and Department of Ecology E Evolutionary Biology, University of Kansas, Lawrence, KS 66045-7561, USA \\ ${ }^{\mathrm{b}}$ Odum School of Ecology, University of Georgia, Athens, GA 30602-2202, USA \\ ${ }^{\mathrm{c}}$ Estación Biológica San Miguel, Reserva Natural Absoluta Cabo Blanco, MINAE, San José, Costa Rica \\ destación Biológica La Selva, Organización para Estudios Tropicales, Apdo. 676-2050 San Pedro, San José, Costa Rica
}

\section{A R T I C L E I N F O}

\section{Keywords:}

Forest recovery

Habitat fragmentation

Neotropics

Wildlife conservation

\begin{abstract}
A B S T R A C T
Reserva Natural Absoluta Cabo Blanco, a strongly seasonal deciduous forest located at the southernmost tip of northwestern Costa Rica's Nicoya Peninsula, was established in 1963 and is the country's oldest nationally protected reserve. The peninsula has been occupied for millennia and is a heavily impacted landscape, and, unfortunately, its biotic diversity is among the most poorly studied in Central America. As part of multiyear studies of the flora and fauna of the region, we assess the changes in vegetation and the terrestrial mammal community from earlier times to the present day. Through historical records, interviews with long-term residents of the area, and our studies over the past decade, we document changes in forest cover, settlement, and land use, and assess the changes in species diversity and in mammal species' abundance. We then discuss the ecology of the mammal species on the peninsula, emphasizing the role that humans have played in influencing population levels.

After 45 years of protection, the forest structure of the 3100 ha reserve differs markedly from that observed in the early 20th Century and it is quite heterogeneous. Species diversity of both the native vegetation and the mammals is substantial in the regenerating forest. The known mammal fauna included at least 37 species of non-flying mammals and 39 species of bats. Six species (Geoffroy's Spider Monkey, Giant Anteater, White-lipped Peccary, Central American Red Brocket Deer, Baird's Tapir, and Jaguar) have been extirpated from the reserve. Poaching of game species continues and will be difficult to eliminate completely. Nevertheless, with regenerating habitats, coupled with protection of wildlife, reestablishment of the reserve's native species has been dramatic both in terms of species diversity and abundance. The reserve is not in a defaunated condition. Many mammalian frugivores, seed dispersers, and/or seed predators are common and most top mammalian predators are present. We present several testable hypotheses regarding the significance of this mammalian community in the context of other Neotropical forest mammal and plant communities. Rapid expansion of tourism in this region has the potential to affect the reserve adversely. In recent years, the reserve has served as an important site for teaching tropical biology courses. Small reserves, such as Cabo Blanco, even if not connected to larger protected areas through corridors, provide critical habitat for native flora and fauna, a source of genetic stock, and valuable regional teaching and research sites.
\end{abstract}

(C) 2008 Elsevier B.V. All rights reserved.

\section{Introduction}

Dry forests once represented more than $50 \%$ of forested regions of Central America, but today considerably less than $1 \%$ of the

\footnotetext{
* Corresponding author. Tel.: +1 785864 4180; fax: +1 7858645335. E-mail address: btimm@ku.edu (R.M. Timm).

${ }^{1}$ Present address: Apdo. 35-5655, Santa Elena de Monteverde, Puntarenas, Costa Rica.
}

original area remains, making dry forest one of the most endangered forest types anywhere (Murphy and Lugo, 1986; Janzen, 1988; Bullock et al., 1995). Janzen (1986) estimated that perhaps $550,000 \mathrm{~km}^{2}$ of dry forest existed on the Pacific lowlands of Mesoamerica in 1500; this has now been reduced to patches of varying sizes with little to no connectivity. Costa Rica, although small in area, is recognized as a leader in Latin American conservation efforts, with over $27 \%$ of the country protected by national or private reserves (SINAC, 2008). Yet Costa Rica's once extensive dry forest now exists only in widely scattered patches or 
as individual trees. In the dry forest of northwestern Costa Rica's Guanacaste lowlands, Sánchez-Azofeifa et al. (2001) estimated that by 1991 only $3 \%$ of the closed forest cover remained, the lowest percentage of any forest type in the country. Although deforestation, habitat fragmentation, intensive agriculture, and illegal hunting continue to occur (Carrillo et al., 2000; Daily et al., 2003; Timm and LaVal, 2000; Quesada and Stoner, 2004; Stoner and Timm, 2004), certain large areas previously logged or cultivated are being allowed to regenerate, and in some areas are being actively managed. There has however, been little documentation of the reestablishment of wildlife populations within areas of regenerating forest anywhere in the tropics. In southern Costa Rica's middle elevation forest, Daily et al. (2003) found that many species of mammals persist in small forest patches $>5 \mathrm{~km}$ from extensive forested areas and that the species to disappear first are the largest members of their families.

Diverse and structurally complex dry forests originally occurred on an array of moisture and soil types across Costa Rica's Nicoya Peninsula (Holdridge, 1967), although the forest had largely disappeared by the late 1970s (Sader and Joyce, 1988). Located at the southern tip of Nicoya Peninsula (Fig. 1), the first protected area in Costa Rica-Reserva Natural Absoluta Cabo Blanco (hereinafter referred to as Cabo Blanco)-was set aside in 1963 to preserve the forest and to protect wildlife. At the time of its establishment, only $15 \%$ of the area of the reserve was in primary forest, with the remaining 85\% under cultivation (Camacho Céspedes et al., 2007). Regrowth of the vegetation during the ensuing 45 years has proceeded without human intervention, and the mammal species have received excellent protection, providing an opportunity to assess processes of wildlife recovery in naturally regenerating tropical forest.

Reserva Natural Absoluta Cabo Blanco owes its existence to the vision of Nils Olof ("Nicolas") Wessberg and Karen Mogensen, who arrived in the area from Scandinavia in 1955. Concerned about the destruction of the forest and hunting of wildlife in the region, they raised approximately \$30,000 between 1960 and 1963 from private sources to purchase the land from landowners. As the culmination of their efforts, Costa Rican President Francisco Orlich Bolmarcich expropriated the land and declared it an absolute nature reserve by executive decree (no. 10) on 21 October 1963.

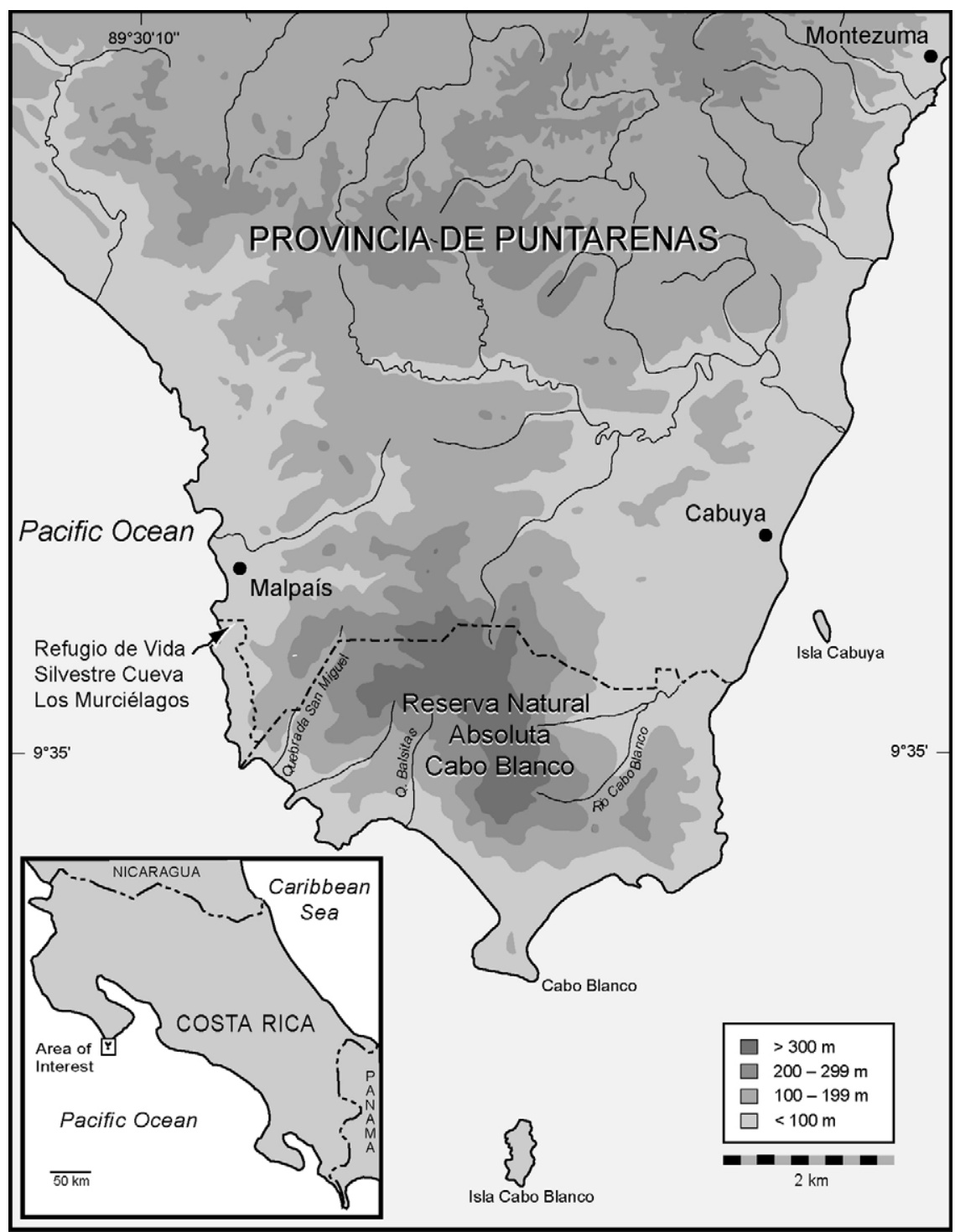

Fig. 1. Map of Costa Rica's southernmost Nicoya Peninsula, showing the locations of Reserva Natural Absoluta Cabo Blanco and Refugio de Vida Silvestre Cueva los Murciélagos in relation to the communities of Cabuya, Malpaís, and Montezuma. The main buildings of the Estación Biológica San Miguel are located just east of the mouth of the Quebrada San Miguel. A countrywide map showing the location of Cabo Blanco on the Nicoya Peninsula appears below. 
Wessberg (1968, p. 15) lamented that "only 50 years ago this region was virtually untouched. Now only the 5 square miles on the tip of the Peninsula was still not destroyed." Wessberg and Mogensen's saga and the political and social context in which it took place are described by Wallace (1992) and Evans (1999); Mogensen recounted the story in her own words over a quarter of a century after the events (Hilje Quiros, 2002), and Boza and Mendoza (1981) and Boza (2006) provide informative, overall histories of Costa Rica's national park system.

During the first 22 years of its existence, Reserva Natural Absoluta Cabo Blanco was entirely closed to the public; scientific research and even photography were not allowed. Access was permitted only to park guards for protection against fire, logging, and poaching. The strict protectionism of the reserve has eased in recent years, first with the opening in 1985 of the Cabuya (eastern) sector for day-visits in response to pressure from residents and tourists (Mensink et al., 1992), and then with the opening in the mid-1990s of the San Miguel (western) sector to a limited number of educational groups and researchers for longer-term visits. The reserve's original area of 1272 ha was increased in 1982 to include the first $1 \mathrm{~km}$ from the shoreline outward, comprising 1750 ha of ocean, and representing the first protected marine habitat of Costa Rica. Most recently, a 40 ha coastal strip in what was formerly Refugio de Vida Silvestre Cueva los Murciélagos was added, connecting the San Miguel sector and the community of Malpaís, and bringing the total extent of the reserve to approximately 3100 ha.

Here we document, through a historical account, changes in land-use and settlement on the southern Nicoya Peninsula's dry forest. We then describe the ecology of the mammal fauna within this region, emphasizing the impact of humans on mammal populations. Finally, we discuss implications for forest regeneration and for management of the mammal fauna in this region and provide hypotheses for future testing.

\section{Methods}

The information presented herein is focused primarily in and around Reserva Natural Absoluta Cabo Blanco at the southernmost tip of Costa Rica's Nicoya Peninsula, Puntarenas Province (Fig. 1). Our primary study site is the general vicinity of Estación Biológica San Miguel $\left(9^{\circ} 35^{\prime} \mathrm{N}, 85^{\circ} 08^{\prime} \mathrm{W}\right), 2 \mathrm{~km}$ south of the community of Malpaís, located in the San Miguel sector (western sector) of the reserve. We also have worked regularly since 2000 in what was a separate, private reserve, then called Refugio de Vida Silvestre Cueva los Murciélagos $\left(9^{\circ} 36^{\prime} \mathrm{N}, 85^{\circ} 09^{\prime} \mathrm{W}\right)$, now administratively within Reserva Natural Absoluta Cabo Blanco. Two of the authors, RMT and DM, have been working and teaching in the reserve regularly since 1999 . The other two authors, DL and ML, first visited the reserve in 1995, and have worked there extensively since, living in the San Miguel sector for weeks at a time. Our species lists and qualitative evaluations of abundances are generated from our personal observations and those of experienced local residents, small mammal trapping projects, and analysis of owl pellets from the caves. Detailed descriptions of the caves and our survey work there have been provided by Timm and McClearn (2007).

The historical information presented here has been assembled in part from the literature and historical documents and in part from interviews with knowledgeable life-long residents of the area. Their vivid recollections of times past and their astute observations of wildlife provide a wealth of insights that helped shape our understanding of the area's ecology. Carlos Castrillo Castrillo served as a park guard under Wessberg and Mogensen, beginning in the early 1970s. Felipe Briceño Herrera, also a park guard, grew up in Cabuya and as a boy worked on his father's farm inside what is now the reserve; Felipe Briceño's father, Guadalupe Aviléz, worked at cutting timber in the coastal forests as a young man, and recounted times in the 1930s and 1940s when many people in the area commonly hunted and ate tapirs, spider monkeys, and both White-lipped and Collared Peccaries. Luz Marina Gómez Gómez grew up near the Cabuya sector of the reserve, and works as a park guard in both the Cabuya and San Miguel sectors. Elias Nuñez García is a resident of the Malpaís area, and worked on his father-in-law's farm in what is now the reserve, just north of the San Miguel sector in the Cuevas los Murciélagos area.

\section{Results}

\subsection{Study site}

The natural vegetation of the southernmost Nicoya Peninsula is classified as Transitional Dry-Moist Tropical Forest in the Holdridge Life Zone System (Holdridge, 1967; Holdridge et al., 1971; Herrera Sota and Gómez Pignataro, 1993; Lindquist, 2003; Mata and Echeverría, 2004). Deciduous trees that drop their leaves each dry season dominate the canopy along the coastal plain, but not inland. In the secondary forests of the coastal strip, the most common trees are madroño (Calycophyllum candidissimum; Rubiaceae), pochote, roble de sabana, corteza negra (Tabebuia impetiginosa; Bignoniaceae), yos (Sapium glandulosum; Euphorbiaceae), ceibo barrigón (Pseudobombax septenatum; Bombacaceae), guanacaste (Enterolobium cyclocarpum; Mimosaceae), and panamá (Sterculia apetala; Sterculiaceae). The common palm species biscoyol (Bactris minor; Arecaceae) and royal palm form aggregations on gentle slopes and terraces; and beach almond or almendro de playa (Terminalia catappa; Combretaceae) and plumeria or flor blanca (Plumeria rubra; Apocynaceae) occur commonly near the shore.

Reserva Natural Absoluta Cabo Blanco is bordered on the west and south by the Pacific Ocean and on the east by the Golfo de Nicoya (Fig. 1). Malpaís lies to the north and northwest; it originally was a small fishing community, but is now a burgeoning tourism destination. The land to the north and northeast is privately owned and includes patches of secondary forest, young second growth or 'charral', and cattle pasture. Outside the reserve, forest cover remains largely intact along stream drainages, forming narrow corridors of forest habitat that extend throughout the area.

\subsubsection{Physical environment}

Cabo Blanco is at the southern tip of the Nicoya Peninsula, which is being uplifted by the subducting Cocos Plate. The peninsula is part of the northern forearc segment, some $50-100 \mathrm{~km}$ northeast of the Middle American Trench, which is an area of active crustal movements including repeated cycles of subduction, uplift events, and tilting of the forearc crust (Marshall and Anderson, 1995; Coates, 1997).

Elevation in the reserve ranges from sea level to $375 \mathrm{~m}$ on Cerro Buenos Aires. The San Miguel sector is composed of a relatively flat coastal strip of land extending some $5 \mathrm{~km}$ in length and varying in width from 50 to $150 \mathrm{~m}$, backed by a slope rising to a terrace of about 300 m elevation. Smaller terraces, which represent ancient sea levels, may be found between 100 and $200 \mathrm{~m}$ elevation.

Records of rainfall, maximum and minimum temperature, relative humidity, wind speed, and cloud cover have been maintained for Estación Biológica San Miguel since 1998. The total annual precipitation ranges from 2500 to $3200 \mathrm{~mm}$ (mean $3000 \mathrm{~mm}$ ), with little variation from year to year (Herrera, 1985; Lindquist and Carroll, 2004). Rainfall is highly seasonal, with a 
marked dry season. As much as $95-100 \%$ of the annual rainfall in San Miguel occurs during the May-November wet season, with almost no rain between January and April. Average annual temperature is $27^{\circ} \mathrm{C}$, varying from an average low of $24^{\circ} \mathrm{C}$ to an average high of $32^{\circ} \mathrm{C}$ (Lindquist, 2003).

Soils in the reserve are formed from weathered marine limestone, mudstone, sandstone, and turbidite (Smith, personal communication). There is a gradient in soil texture from the coastal terraces inland, with sandier soils near the coastline and clay-rich soils inland (Lindquist, 2003). The soils in general remain nutrientrich, even after decades of cultivation and cattle grazing (Camacho Céspedes et al., 2007). The rocky shores and headlands are themselves made up of extensive turbidite beds strewn with stream-worn limestone cobbles and pebbles.

The hills and slopes are crisscrossed by streams fed both by runoff, which is highly seasonal, and by springs, some of which are active year-round. All of the streams, including even the largest, Quebrada San Miguel, dry up during the end of the dry season, leaving widely scattered small pools and spring-fed trickles of water between February and May.

The rocky intertidal zone is relatively flat in profile, and the daily tidal range is large-as much as $3 \mathrm{~m}$ vertical difference between low tide and high tide; thus extensive areas of tide pools with an abundance of small fish and marine invertebrates are exposed twice daily at low tide. These tide pools are an important resource for raccoons and White-tailed Deer; raccoons are foraging on invertebrates and deer presumably are drinking saline water. Deer are especially vulnerable to poachers when they are exposed in these open areas.

\subsubsection{Land use history}

Timm and McClearn (2007) reviewed the history of land use on the Nicoya Peninsula and identified six stages. We briefly outline the first four stages and amplify in greater detail the final two stages-early and mid-20th century agriculture and forest regeneration-because of their direct relevance to the current abundance and distribution of mammals.

(1) The Pre-Columbian period (before 1500), with moderate but fluctuating settlement sizes for several thousands years, exploitation of coastal and forest resources, clearing for agriculture, but probably no large-scale deforestation. Costa Rica's northwestern Pacific lowlands were the center of an agricultural society collectively known as the Chorotega. Maize was important in the diet by 2000 B.C. (Quesada López-Calleja, 1980 ), and by 500 B.C. the Chorotega had extensive villages, complex chiefdom societies, and high population densities. They relied upon mixed agriculture primarily based on maize, beans, and squash. Thus, before arrival of the Spanish in Costa Rica in 1502, there had already been considerable clearing of forest for agriculture on the Nicoya Peninsula. Also see Timm (2000) for a summary of Pre-Colombian land use in northwestern Costa Rica.

(2) Early colonial period: depopulation, land abandonment and/or a shift of population centers, and the introduction of Old World crops and livestock during the two centuries following contact with the Spanish (Whitmore and Turner, 1992). By the early 1600 s, the Spanish were logging the remaining valuable timber trees at the base of the Nicoya Peninsula and along the coasts, especially mahogany or caoba (Swietenia spp.; Meliaceae), Spanish cedar or cedro amargo (Cedrela odorata; Meliaceae), and balsa of Peru and balsa wood (Myroxylon spp.; Fabaceae). Large-scale cattle and mule ranches were well established throughout the peninsula and northwestern Costa Rica during the 1600s (Molina and Palmer, 2000). Extensive cattle haciendas in the vicinity of Cabo Blanco itself are mentioned in an eyewitness account of the burial of the pirate captain John Cook on that shore in 1684 . When a handful of pirates attempted to drive off cattle to resupply their vessels, they were turned back by 50 -armed Spaniards who pursued them to the edge of the sea cliffs where the pirates made good their escape (Incer, 1990).

(3) Subsistence agriculture, some larger plantations, and livestock raising on the peninsula (Gudmundson, 1983), but with most of the backbone of the peninsula and much of the Pacific coast remaining forested for the next 250 years. Having sailed along the coast around 1920, Victor Bravo later told Wessberg that he had seen only forest and no people, and was awed by the beauty of the forest (Wallace, 1992). Aerial photographs taken in the 1940s substantiate the first-hand accounts from this period that much of the peninsula was forested (see also Gómez, 1986).

(4) Increasing populations and agricultural activities in the north of the peninsula (from the town of Nicoya northward) as compared with the tip of the peninsula. Human settlement and development of commerce proceeded slowly in the area from Manzanillo through the Montezuma area to Cabo Blanco. The area remained forested and inaccessible with few roads and trails; most travel was by motor launch around the coast (Wallace, 1992; Hilje Quiros, 2002; Castrillo, personal communication). Residents of the Cabo Blanco area at that time recall that wildlife was abundant, and specifically mention several species that have since been extirpated: Baird's Tapir, White-lipped Peccary, Central American Red Brocket Deer, Geoffroy's Spider Monkey, and Jaguars (Briceño, personal communication).

(5) Rapid deforestation during the late 1940s up to the present time. Forest clearing with subsequent soil erosion during the rainy seasons was particularly destructive during the boom of the cattle industry in the early and middle 1900s, throughout the moist forest and tropical dry forests of the peninsula. In the southern part of the peninsula from Samara to Montezuma, including Cabo Blanco, logs of pochote (Bombacopsis quinata; Bombacaceae), corteza amarilla (Tabebuia ochracea; Bignoniaceae), roble de sabana (Tabebuia rosea; Bignoniaceae), and cedro amargo were skidded with teams of oxen (yoked together but working without carts) to the beach, where the logs were tied together as rafts and floated out to waiting boats. This continued until the early 1960 s, and ceased only when the desirable timber species had become scarce (Briceño, personal communication). All of the work was done by hand, with axes and machetes; chainsaws did not appear in the area until the 1980s (Castrillo, personal communication). Forest clearing for cattle pastures and agriculture took place concurrently with logging and the sale of timber. Details and aerial images of the deforestation on the Nicoya Peninsula during this time period, as well as elsewhere in Costa Rica, are provided by Joyce (2006).

(6) Regrowth of secondary forest in the area now set aside as the Reserva Natural Absoluta Cabo Blanco. Since 1963, forest regeneration and succession in the reserve has proceeded, without intervention or active management of any kind; the 45-year-old secondary forest now growing in the reserve has arisen through natural processes of recruitment and establishment. In unprotected areas on the Nicoya Peninsula, outside of reserves, the rapid expansion of the tourism industry, and especially the development of hotels and golf courses, has been responsible for the loss of many forest patches and for degradation of the matrix habitat. However, tourism also is responsible for protection of some patches of forested habitats, where owners of hotels and resorts have the foresight to recognize forest fragments as attractive to many tourists. 


\subsubsection{Vegetation}

The natural vegetation of the Cabo Blanco region is classified as Transitional Dry-Moist Tropical Forest in the Holdridge Life Zone System (Holdridge, 1967; Holdridge et al., 1971; Herrera Sota and Gómez Pignataro, 1993; Lindquist, 2003; Mata and Echeverría, 2004). To date, 249 plant species belonging to 86 families have been identified in Cabo Blanco; the woody flora is described in detail by Camacho Céspedes et al. (2007).

\subsubsection{Before the reserve}

By 1950 , some 15 years before the establishment of the reserve, much of the forest of the San Miguel sector had been cleared for agricultural use, with the exception of some areas of primary gallery forest near the coast, occasional patches of disturbed forest, and trees left behind as shade for cattle. The usual procedure was to fell trees, burn the slash, and then plant crops (Briceño, personal communication). Some of these felled trunks were later skidded to the shore and sold to timber merchants. By the mid-1960s, few large timber trees of economic importance remained (Castrillo, personal communication). The $15 \%$ of the area that was left in primary forest is primarily to the east of San Miguel, in the Cabuya sector.

During the 1950s and 1960s, the coastal strip from Quebrada San Miguel to Playa Balsitas was planted in maize (Zea maize; Poaceae), rice (Oryza sativa; Poaceae), the small plantain known as cuadrado (Musa sp.; Musaceae), yuca (Manihot esculenta; Euphorbiaceae), and beans (frijoles negros and rojos, Phaseolus vulgaris; Fabaceae). Beans were planted using the traditional method of "tapando frijoles," in which the dried seeds are broadcast over old, drying maize stalks which have been chopped and left on the ground following the harvest. This provides the humid conditions that favor germination, a raised mat of drying cornstalks above ground level upon which the young bean plants can climb, and a source of organic matter and mineral nutrients that are released into the soil as the old corn stalks decompose.

The slopes also were planted, often in beans, although the steepest slopes were left in forest. The highest inland terraces, especially around Maven, were converted to cattle pastures. Cattle were allowed to wander and forage freely in the forest. The pattern of early land use reflects both topography and the economic resources of the various landowners-those with more limited means could not afford cattle and therefore planted crops (Castrillo, personal communication).

As many as $12-16$ families settled within what is now the reserve in the late 1950s-early 1960s, living in rustic houses built of wooden poles, hand-sawn boards, and walls and roofs thatched with fronds of royal palm (or palma real, Attalea butyracea $=$ Scheelea rostrata; Arecaceae). Around their homesteads they planted mango (Mangifera indica; Anacardiaceae), papaya (Carica papaya; Caricaceae), guayaba (Psidium guayaba; Myrtaceae), and lemon trees (Citrus sp.; Rutaceae) (Castrillo and Nuñez, personal communication).

\subsubsection{Post- 1963}

The present forest of the San Miguel sector is mostly tall, wellformed, dense secondary forest which started regrowth around 1963 when the reserve was established. The regeneration of the San Miguel forest vegetation following the abandonment of cultivated fields and pastures has been rapid, producing in only 45 years a forest reported by Lindquist (2003) to be comparable in stem density, basal area, and floristic composition to the remnant primary forest patches in the reserve.

The secondary forest canopy is some $20-35 \mathrm{~m}$ tall, and the largest trees exceed $1 \mathrm{~m}$ in diameter. Most of the trees have clear boles with branches at crown level, indicating that they almost certainly grew up in very high-density sapling stands. Other large trees have multiple trunks, suggesting that they arose from stump sprouts. Sprouting may take place following stem breakage caused by strong winds, damage from falling trees, or cutting by man. Some multiple stems start around waist height, which is typical of trees that were originally felled with axes or machetes. The secondary forest is not well stocked with all size classes, lacking individuals in certain parts of the size range and with an overabundance of stems in others (Lindquist, 2003), indicating that the area had been cleared and regrowth of trees has progressed as cohorts.

The structure and species composition of the forest varies appreciably as one moves from the narrow coastal terrace to the slopes above the coastal strip and then to the higher elevation inland terraces. Topography and distance from shore appear to be important influences on the vegetation, as does herbivory by harlequin land crabs (Gecarcinus quadratus; Gecarcinidae) which feed on seeds and young seedlings (Lindquist, 2003; Lindquist and Carroll, 2004).

The forest at higher elevations and on slopes includes several of the aforementioned tree species, especially madroño, in addition to espavel (Anacardium excelsum; Anacardiaceae), zonsapote (Licania arborea; Chrysobalanaceae), chicle (Manilkara chicle; Sapotaceae), almendro (Andira inermis; Papilionaceae), ojoche (Brosimum alicastrum; Moraceae), guava (Inga vera; Mimosaceae), and guácimo colorado (Luehea seemannii; Tiliaceae). The understory has an abundance of black peppers (Piper spp.; Piperaceae), juvenile manteco (Trichilia martiana; Meliaceae), and corteza amarilla.

Where maize was cultivated in San Miguel, the most common weed of the cornfields was the liana Adenocalymna inundatum (Bignoniaceae) (Castrillo, personal communication). This aggressive, fast-growing species propagates both sexually and vegetatively, and after the fields were abandoned it continued to thrive and spread. At present, it forms either an abundant canopy liana where it encounters trees to climb, or a dense, dominant understory shrub forming a virtual monoculture 1-1.5 m tall.

Along the shoreline, the weedy, fast-growing coastal shrub beach hibiscus (Talipariti tiliaceum; Malvaceae) forms a nearly impenetrable monospecific stand. The dense cover of both beach hibiscus and Adenocalymna appears to impede forest regeneration, because these thickets have few tree seedlings growing beneath them. The large terrestrial bromeliad Bromelia penguin likewise forms dense patches near the shore, spreading vegetatively as well as by seed.

The forest shows considerable patchiness, with marked variation in structure and composition over even short distances. More detailed studies are needed to explore the possible correspondence between current forest structure and composition and former land use in these patches.

Genetic diversity does not differ in Cabo Blanco between primary and secondary forest populations of two common canopy tree species, guanacaste (animal dispersed) and guácimo colorado (wind dispersed); genetic diversity was found to be high in both the primary and secondary forest (Case and Hamrick, 2001; Camacho Céspedes et al., 2007). Likely seed sources for regeneration of the forest during the past 45 years would include nearby primary forest populations as well as trees growing outside the reserve. The soil seed bank as well as regrowth from stump sprouts also probably contributed to much of the regeneration.

There is no evidence that the regrowth of forest in San Miguel followed an orderly succession of species. The earliest arrivals in the abandoned pastures and fields apparently were a representative sample of the forest assemblage as a whole. The secondary forest today includes a mixture of weedy, fast-growing, shade- 
intolerant species and slower-growing, shade-tolerant species, all of which appear to have arrived and become established more or less concurrently. Detailed studies of the demography of trees in primary and secondary forest areas throughout the reserve could help in the reconstruction of the processes involved.

Factors that may influence succession include a number of biotic factors such as sites of previous crops, holding pens for livestock, etc. Abiotic factors also impact the heterogeneous nature of regeneration. We have documentation of two tornadoes having passed through Cabo Blanco; both causing damage to trees and shrubs. A severe tornado passed through in the San Miguel sector of the reserve in September 2007, causing considerable damage to trees and buildings. A smaller and less destructive tornado occurred approximately 35 years ago, but there have been no others on record or in recent memory (Nuñez, personal communication).

Some aspects of the physical structure of the secondary forest, notably stem density and basal area, are now comparable to those of the primary forest (Lindquist, 2003). Pronounced differences remain, however, in size class distributions, because the secondary forest is not well stocked in all size classes. Tree growth rates, time to reproductive maturity, and reproductive rates of the species in San Miguel should all influence the length of time necessary for the size class distribution of trees to achieve the steady-state size distribution expected for a mature, mixed-age stand.

Camacho Céspedes et al. (2007) provided a broad overview of and identification guide to the trees found in the reserve and descriptions of most species. Further details on the history, habitats, and vegetation of Cabo Blanco have been presented by Lindquist (2003), Lindquist and Carroll (2004), Camacho Céspedes et al. (2007) and Timm and McClearn (2007).

\subsection{The mammal fauna}

\subsubsection{Contemporary food availability for mammals}

Several palm species are important as food sources for mammals in San Miguel, including royal palm and coconut palm (Cocos nucifera; Arecaceae). Variegated Squirrels (Sciurus variegatoides) chew through the tough coconut pericarp while the coconuts are still on the tree and feed on the pulp inside. A wide array of mammals (such as opossums, White-faced Capuchin Monkeys, Variegated Squirrels, agoutis, Pacas, coatis, raccoons, Gray Foxes, Coyotes, and White-tailed Deer) eat the fruits or seeds of royal palm, which are abundant year-round.

Other tree species fed upon by frugivorous and omnivorous mammals include beach almond, jocote (Spondias purpurea; Anacardiaceae), and capulín (Muntingia calabura; Elaeocarpaceae). Several abundant understory Piper species comprise an essential food source for bats of the genera Carollia and Sturnira; Piper grows abundantly away from the marine influence and is most abundant along streams. Both the treelet Piper tuberculatum and the shrub Piper reticulatum bear flowers and fruits for at least 10 months of the year from January to October (Lindquist, 2003; Camacho Céspedes et al., 2007). Brosimum alicastrum and B. costaricanum can produce massive fruit crops (Camacho Céspedes et al., 2007) that are consumed by the Great Fruit-eating Bat (Artibeus lituratus) and Jamaican Fruit-eating Bat (Artibeus jamaicensis). The nectarfeeding glossophagine bats feed upon and pollinate flowers of pochote, a common canopy tree, which flowers early in the dry season between December and February (Camacho Céspedes et al., 2007). The woody fruits of Luehea, a fast growing pioneer, were reported to be an important food for "deer, coyotes, and several other mammalian species" at Cabo Blanco by Boza and Mendoza (1981, p. 183).

Generalist feeders, especially raccoons, coatis, and spotted skunks, exploit the large populations of harlequin crabs that range inland from the shoreline for nearly a kilometer. Harlequin crabs reach peak density and activity, and spend substantial periods away from their burrows, during their breeding season in AprilJune; their numbers vary markedly seasonally and from year to year. Other coastal and freshwater invertebrates provide additional food for both raccoons and coatis. Otters (Lontra longicaudis) have been observed capturing and eating freshwater shrimp in the Quebrada San Miguel.

\subsubsection{Hunting}

Local residents through the 1940 s relied heavily upon native mammals, birds, and marine fishes for protein. Among the mammal species most favored for meat and regularly hunted in the 1920s, 1930s, and 1940s by residents of the area were Pacas, Collared Peccaries, White-lipped Peccaries, tapirs, White-tailed Deer, and Geoffroy's Spider Monkeys (Briceño and Castrillo, personal communication). The number of species harvested for meat represents a small fraction of the mammal fauna in the area, but constitute a large proportion of those species weighing more than $5 \mathrm{~kg}$. Details of how each game species was hunted and used, as well as information on their distribution and current status, are presented in the species accounts that follow.

\subsubsection{Ecology and natural history of mammals at Cabo Blanco- systematic accounts}

In the following accounts of mammals from the southern Nicoya Peninsula, 37 terrestrial species belonging to 9 orders and 18 families are included on the basis of documentation of their existence in the area. In addition, comments are made on two introduced species whose presence in the region lacks adequate documentation. English and local Spanish names are given for each species. Spanish names are those used in the area.

3.2.3.1. Order Didelphimorphia, Family Didelphidae (Opossums), Caluromys derbianus, Derby's Woolly Opossum; Zorro de Balsa. Derby's Woolly Opossums are found from Veracruz, Mexico, south through Central America into western Colombia and northwestern Ecuador. In Costa Rica, Caluromys derbianus occurs from sea level to about $1600 \mathrm{~m}$. Two subspecies are recognized in Costa Rica; $C$. derbianus pallidus from the Pacific lowlands and slopes and $C$. derbianus centralis from the Caribbean lowlands and slopes.

Woolly opossums have been observed in the reserve on a couple of occasions. The best-documented observations were by D. and M. Lieberman, who closely observed and photographed an adult-sized female foraging over several nights at the buildings of the San Miguel station in early and mid-July 2008.

3.2.3.2. Didelphis virginiana, Virginia Opossum; Zorro Pelón. Virginia Opossums are widespread on the Nicoya Peninsula. Two species of Didelphis are found in Costa Rica, D. marsupialis and D. virginiana. Although we have not examined specimens from Cabo Blanco, we believe the species to be $D$. virginiana because it is the common species in the dry forest. Didelphis marsupialis is primarily a species of the higher elevations and wet forests. Two color morphs of $D$. virginiana are present in western Costa Rica, a dark, nearly black color morph and a paler, gray morph. Because $D$. marsupialis is dark, nearly black, and the dark color morph of $D$. virginiana is often similar in color, the species of Didelphis are often misidentified and best distinguished using cranial characters.

On the Nicoya Peninsula, opossums are considered to be slow-witted. They are held in disfavor because they kill chickens and are hunted with dogs for that reason. Although not killed for meat per se, the meat may be consumed, and is generally cooked in a stew. Opossums are most frequently shot with 16-gauge shotguns. 
3.2.3.3. Marmosa mexicana, Mexican mouse opossum; Zorra or Zorricí. We were told by independent observers that mouse opossums were observed at Cabo Blanco, but we did not observe them ourselves. The species groups of mouse opossums in Costa Rica include the small Mexican Mouse Opossums (Marmosa mexicana complex) and the larger Alston's Mouse Opossum (Micoureus alstoni). Because Alston's Mouse Opossum is a mid and high elevation species and the Mexican Mouse Opossum is widespread, albeit uncommon in the dry forest, we are confident that the mouse opossums observed were the Mexican Mouse Opossum.

3.2.3.4. Order Chiroptera, six families, bats; Murciélagos. Timm and McClearn (2007), as part of a companion study, recently reported that 39 species of bats are known from the reserve. Their multiyear survey in the reserve and in the adjacent Refugio de Vida Silvestre Cueva los Murciélagos attempted to quantify species diversity, abundances, habitat use, seasonality, and reproduction of the region's bats. They documented that the bat fauna includes 5 species of emballonurids, 1 mormoopid, 1 noctilionid, 21 phyllostomids, 7 vespertilionids, and 4 molossids. Several species have clear habitat preferences. The 2 most commonly captured bats, Carollia perspicillata and Artibeus jamaicensis, are abundant in both the inland and coastal forests and both are more abundant we did not observe them ourselves in the rainy season than in the dry season. The largest animal-eating bats (Noctilio leporinus, Chrotopterus auritus, Phyllostomus hastatus, Trachops cirrhosus, and Vampyrum spectrum) are present, but the small and middle-sized predatory bats (Micronycteris, Lophostoma, and others) are poorly represented both in terms of diversity and abundance. Several species of bats, including Balantiopteryx plicata, Saccopteryx bilineata, Noctilio leporinus, Artibeus watsoni, Desmodus rotundus, Glossophaga soricina, Phyllostomus hastatus, Trachops cirrhosus, Lasiurus ega, and Myotis nigricans, seem to be equally abundant in both seasons. Most species had distinct seasonal reproductive activity; only common vampires breed throughout the year. The species records and abundances of several other species differed between Cabo Blanco and the Parque Nacional Palo Verde (Stoner and Timm, 2004), a dry forest site also in Costa Rica's Pacific lowlands and approximately $84 \mathrm{~km}$ to the north. Although both sites are relatively close together in the northern Pacific lowlands of Costa Rica, Cabo Blanco is substantially wetter, and the associated differences in vegetation may be driving bat distributional patterns. Timm and McClearn (2007) report ecological information for bats on the Nicoya Peninsula and document that bat diversity and abundances can be substantial in regenerating forest. Several of the most commonly captured bat species are seed dispersers and may be critical to forest regeneration.

3.2.3.5. Order Cingulata, Family Dasypodidae (Armadillos), Dasypus novemcinctus, Nine-banded Armadillo; Cusuco. The Nine-banded Armadillo is the most widely distributed armadillo, occurring from the midwestern and southeastern United States to southeastern Brazil and northeastern Argentina. The subspecies Dasypus novemcinctus fenestratus is found throughout Costa Rica, except at higher elevations.

Armadillos are common in the reserve as well as throughout the region. The predators of armadillos in the region include Coyotes, Pumas, and boas (Boa constrictor). Armadillos generally are hunted with dogs during the day in dry pastures. We were told that a hunter waits until the animal comes out of its hole, then he grabs it and breaks its neck. The meat may be fried, cooked in a stew, or grilled; however, some people do not eat armadillos, considering them unsuitable for human consumption. The bony armadillo carapace traditionally has been used in this area for making jewellery boxes. There appear to be fewer armadillos now than in the past, both inside and outside the reserve (Castrillo, personal communication).

3.2.3.6. Order Pilosa, Family Myrmecophagidae (Anteaters), Myrmecophaga tridactyla, Giant Anteater; Oso Hormiguero. Giant Anteaters were once found throughout Central America and tropical South America to Uruguay and northern Argentina. In Costa Rica, anteaters occurred from the Pacific and Caribbean coasts to nearly the highest elevations (Timm et al., 1989); the Central American subspecies is treated as Myrmecophaga tridactyla centralis, although geographic variation has never been critically assessed in this species.

Throughout Central America, Giant Anteater numbers have been severely reduced in the last several decades due to overhunting and habitat destruction. We were told of Giant Anteaters being seen on the Nicoya Peninsula near Santa Cruz de Nicoya several decades ago, but there have been no recent reports of anteaters in the dry forest of Guanacaste and Puntarenas provinces. Although there are no documented records of Giant Anteaters on the southern Nicoya Peninsula, there is every reason to assume that they occurred there historically and were extirpated decades prior to the formation of the reserve.

In the 1970 s and early 1980 s, sightings of Giant Anteaters were made at La Selva and Corcovado (Timm et al., 1989; Timm, 1994), Rincón de la Vieja (Rodríguez and Chinchilla, 1996), and Rara Avis. However, in recent years, observations have been reported only from remote areas in the Talamancan and Tilarán ranges, Parque Nacional Corcovado, and the Reserva Forestal Golfo Dulce. The best-documented observations we are aware of are of an animal killed in the Talamancas in the late 1990s and a camera trap photograph taken recently on the Osa Peninsula. Indiscriminate hunting and the animal's specialized diet are likely responsible for the demise of this species. Giant Anteaters must be considered extremely rare in Costa Rica and in danger of extinction. Giant Anteaters are classified as species in danger of extinction, by Costa Rica's Ministerio del Ambiente y Energía (SINAC, 2008).

3.2.3.7. Tamandua mexicana, Northern Tamandua; Oso Hormiguer$o$. Northern Tamanduas are found from southern Mexico to northwestern Venezuela, western Colombia, western Ecuador, and western Peru. The subspecies Tamandua mexicana chiriquensis occurs throughout Costa Rica from sea level to $1500 \mathrm{~m}$.

Tamanduas are common in the region and frequently encountered throughout the reserve. Lone individuals are seen year around. They are especially abundant in the San Miguel sector in the coastal forest. In our work throughout the Neotropics, we have found tamanduas more numerous in Cabo Blanco than anywhere else. They can be regularly seen foraging in royal palms, apparently feeding on the ants that are found in large numbers at the bases of the dead and decaying fronds. We also regularly see evidence of tamanduas having foraged on rotting logs and on nests of termites of the genus Nasutitermes. The numbers of anteaters in the region appear not to have changed much in past couple of decades (Castrillo, personal communication). Tamanduas are not hunted in this area, but are killed accidentally by automobiles along the roads outside of the reserve.

3.2.3.8. Order Primates, Family Cebidae (New World Monkeys), Alouatta palliata, Mantled Howler Monkey; Mono Congo. Mantled Howler Monkeys are found from southern Mexico south through Central America to extreme northwestern South America, where they occur on the western slopes of the Andes in Colombia and Ecuador to Guayaquil. Howler monkeys are found from sea level to forested high elevations in Costa Rica to at least $2500 \mathrm{~m}$. The 
nominate race, Alouatta palliata palliata, is widespread in Costa Rica, including throughout the Nicoya Peninsula; A. p. aequatorialis is restricted to extreme southwestern Costa Rica on the Osa Peninsula. The ecology of howler monkeys in Costa Rica was reviewed by Glander $(1980,1983)$. Alouatta palliata is classified as a species in danger of extinction, by Costa Rica's Ministerio del Ambiente y Energía (SINAC, 2008).

Howler monkeys are seen regularly and heard commonly throughout the reserve. Troops of up to 20-25 individuals are seen frequently (daily) moving or feeding in the San Miguel area. Lone males are regularly seen. The number of howler monkeys appears to have increased in the reserve in recent years and we consider the species to be common there. Howlers also are commonly seen and heard in forest patches outside the reserve, but in lower numbers. Wessberg (1968, p. 15) wrote that howler monkeys are "seen and heard everywhere." In a series of surveys of the primates at Cabo Blanco, from the dry season of 1988 through the dry season of 1990 , Lippold $(1988,1989,1990)$ found that howler monkeys also were abundant in the eastern sector of the reserve. Howler monkeys generally have not been hunted in this area (Castrillo, personal communication).

3.2.3.9. Ateles geoffroyi, Geoffroy's spider monkey; Mono Araña or Mono Colorado. Geoffroy's Spider Monkey is primarily a Central American species occurring from southern Mexico to northern Colombia. A distinctive gray subspecies, Ateles geoffroyi frontalus, is endemic to the northern Pacific lowlands of Costa Rica and Nicaragua, although it is now extirpated from much its previous range, due to overhunting and forest destruction. Mogensen (quoted in Wallace, 1992, p. 9) stated that this subspecies once lived all along the western side of the Nicoya peninsula. Spider monkeys are classified as a species in danger of extinction, by Costa Rica's Ministerio del Ambiente y Energía (SINAC, 2008).

Spider monkeys were abundant in the forests of the Cabo Blanco area as late as the 1940 s, and were hunted with rifles for their meat (Briceño and Castrillo, personal communication). Although their numbers were clearly in sharp decline, they persisted in Cabo Blanco until the reserve was formed. Wessberg (1968, p. 15) wrote that the "gray miriki monkeys are still few, but I cannot see why they too should not become common." Later, Mogensen recalled that the last 10 spider monkeys in Cabo Blanco were killed by an unscrupulous park guard for the oil in their fat (Wallace, 1992). The oil in the fat of spider monkeys was highly prized for medicinal purposes throughout Costa Rica (Timm and LaVal, 2000). Wallace (1992, p. 9) stated that "These monkeys were the last of an endemic subspecies, Ateles geoffroyi frontalus, that once lived all along the western side of the peninsula. They were a beautiful gray color...."

Spider monkeys occur elsewhere in the region, notably in Reserva Biológica Curú, located approximately $30 \mathrm{~km}$ to the northeast of Cabo Blanco. The spider monkey population in Curú, however, is seemingly an interbreeding mix of individuals from elsewhere in Costa Rica that have been introduced there and have bred with the few remaining individuals that were endemic to the peninsula. During the early years of the reserve, administrators advertised for spider monkeys to be rehabilitated and released and animals were brought there. Therefore, the spider monkeys currently occurring at Curú should not be assigned to the endemic dry forest subspecies, A. geoffroyi frontalus or to any subspecies.

3.2.3.10. Cebus capucinus, White-faced Capuchin; Mono Cara Blanca. White-faced Capuchins are found from eastern Honduras and Nicaragua south though Costa Rica to northwestern Colombia and Venezuela. A single subspecies, Cebus capucinus imitator, is found in Costa Rica from sea level to $3000 \mathrm{~m}$. This widely distributed species is adapted to a wide variety of habitat types. The ecology of White-faced Capuchins in Costa Rica was reviewed by Freese (1983). Although White-faced Capuchins are classified as species with "reduced populations," by Costa Rica's Ministerio del Ambiente y Energía (SINAC, 2008), they are in fact fairly common where suitable habitat occurs.

White-faced Capuchins are one of the most abundant and frequently seen animals at Cabo Blanco. They can be observed on a daily basis if an effort is made to locate them. Cebus capucinus is often observed in groups of 4-15; however, lone individuals, most likely males, are observed occasionally. Capuchins appear to be more numerous in the reserve than in years past. They also occur in forest patches outside the reserve, although at lower densities, and we consider them common in the area. Wessberg (1968, p. 15) wrote that capuchin monkeys are "seen and heard very often...."

3.2.3.11. Order Rodentia, Family Cricetidae (New World Rats and Mice, etc.), Oligoryzomys fulvescens, Fulvous Colilargo Mouse; Ratón. The long-tailed mice of the genus Oligoryzomys constitute a complex of a number of species that remain to be elucidated. The number of valid species in this genus might be shown to be as high as 25-30 when the systematics of these mice are better understood (Carleton and Musser, 1995; Musser and Carleton, 2005). The name generally used for populations in the Central American lowlands is $O$. fulvescens, but the name $O$. costaricensis may be applicable to the Costa Rican lowland and mid-elevation forms. In Costa Rica, these mice are frequently observed in open grassy and weedy habitats.

We found the skulls of several Oligoryzomys in owl pellets in two of the caves at Cueva los Murciélagos. In our surveys of the caves, we found a Barn Owl (Tyto alba) roosting within the caves on many of our visits, both during the rainy season and the dry season. The most abundant prey species we found in the owl pellets was the Southern Cotton Rat (Sigmodon hirsutus); Oligoryzomys fulvescens was the second most abundant species consumed by the owls.

3.2.3.12. Oryzomys couesi, Coues's Marsh rat; Ratón. Coues's Marsh Rat is found from southern Texas and eastern Mexico to the Caribbean lowlands of extreme northern Colombia. This is a widespread, although generally uncommon, mouse in appropriate lowland habitats in Costa Rica. The systematic status of Oryzomys couesi has long been in a state of flux and Timm (unpublished) has found that the populations in the Pacific lowlands differ, probably at the specific level, from those in the Caribbean lowlands.

Oryzomys couesi can be a common mouse and we have observed it in large numbers around lagoons along the Pacific Coast However, it is decidedly not abundant at Cabo Blanco, perhaps because the upland, dry nature of the habitat is only marginal for this species. The few that we have observed were always in buildings. An adult female that was near term was found on 3 February 2001, and an immature that was only a few days old was found in a building on 2 February 2001.

3.2.3.13. Sigmodon hirsutus, southern cotton rat; Ratón. Cotton rats of the genus Sigmodon constitute a complex of several species the taxonomic and geographic limits of which have yet to be resolved in Central America. The species name that was used until recently for the cotton rats in Costa Rica is S. hispidus; however, recent systematic studies have demonstrated that the cotton rats in Nicaragua, Costa Rica, and into northern Colombia and Venezuela merit recognition as a separate species, S. hirsutus.

In Costa Rica, cotton rats are most abundant along the Pacific lowlands and middle elevation slopes, but with the expansion of agriculture and pastures, their range has expanded, as have their numbers, to the point where they are an agricultural pest. Southern Cotton Rats may be extremely abundant in weedy gardens, 
overgrown pastures, and cultivated fields, especially sugar cane. On every occasion that we found Barn Owl pellets in Cueva los Murciélagos, cotton rats were the most abundant prey items observed as judged by the numbers of skulls.

3.2.3.14. Family Cuniculidae (Pacas), Cuniculus paca, Lowland Paca; Tepezcuintle. Pacas, the largest rodents in Costa Rica, are found from east-central Mexico south through all of Costa Rica and the northern two-thirds of South America to Paraguay, Uruguay, and southeastern Brazil. Two subspecies are recognized in Costa Rica: Cuniculus paca nelsoni in the northwestern Guanacaste region and C. p. virgatus throughout the rest of the country, including the Nicoya Peninsula.

Pacas have been and still remain the favored game animal of hunters in this area, as in all of rural Costa Rica, because of the quality of the meat. Indeed, it is the most prized meat of any game species, and families typically share paca meat with neighbors when it is available. Pacas are hunted with .22 rifles at night using dogs, which find them in burrows or in holes in tree trunks. Boas and Coyotes are natural predators of pacas on the Nicoya Peninsula. Once very abundant throughout the region, the numbers declined in the past, but Lowland Pacas now appear to be rebounding in Cabo Blanco (Castrillo, personal communication) and it is relatively common to see them along waterways at night.

3.2.3.15. Family Dasyproctidae (Agoutis and Acuchis), Dasyprocta punctata, Central American Agouti; Guatusa or Cherenga. Agoutis occur from southern Mexico to extreme northern Argentina. They are found in Costa Rica from sea level to at least $2400 \mathrm{~m}$.

Agoutis are not hunted in this region because their meat is not especially favored and they seemingly do little damage to crops (Castrillo, personal communication). They appear to be somewhat more common now in the San Miguel sector than they were previously. Agoutis dig up and eat sweet potatoes, yuca, and other root crops at Monteverde where they are protected and populations have rebounded.

3.2.3.16. Family Erethizontidae (New World Porcupines), Coendou mexicanus, Mexican Hairy Porcupine; Puercoespín. Mexican Hairy Porcupines are found from east-central Mexico to western Panama. The subspecies Coendou mexicanus laenatus is found throughout most of Costa Rica from sea level to about $3000 \mathrm{~m}$.

Porcupines are common in the reserve and throughout the dry forest of the Nicoya Peninsula. Although not hunted deliberately in this area, porcupines are killed when hunters with dogs come across them, presumably to protect the dogs. The meat is not eaten. Porcupines apparently now are seen less frequently in the reserve than in the past (Castrillo, personal communication).

3.2.3.17. Family Heteromyidae (spiny pocket-mice, etc.), Liomys salvini, Salvin's spiny pocket-mouse; Ratón. This spiny pocketmouse is found from Oaxaca to central Costa Rica. In Costa Rica, the nominate subspecies Liomys salvini salvini is restricted to the lowland Pacific dry forest of Guanacaste Province, where it occurs from sea level to at least $1100 \mathrm{~m}$. Liomys salvini may be exceedingly abundant in the dry forest, with populations undergoing considerable fluctuations from year to year.

We found this spiny pocket-mouse to be an abundant species inland at Cabo Blanco; however, it is not uniformly distributed. This forest-floor pocket-mouse occurs inland, with populations seemingly increasing in density with distance from the shore. In catching small rodents and crabs in Sherman live traps, we discovered that the number of crabs decreases as one travels from the shore inland, and that the numbers of spiny pocket-mice increase. Spiny pocket-mice are found a kilometer from the ocean and farther inland. We suspect that either competition with or predation by crabs limits the populations of these seed-eating mice. Skulls of the spiny pocket-mouse were abundant in Barn Owl pellets in the caves at Cueva los Murciélagos.

3.2.3.18. Family Sciuridae (Squirrels, etc.), Sciurus variegatoides, Variegated Squirrel; Ardilla or Chiza. Variegated Squirrels are found from southern Mexico into Panama. In Costa Rica, eight subspecies of Sciurus variegatoides have been recognized, based primarily on color patterns; however, this largest of Costa Rica's squirrels is extremely variable geographically and the specific and subspecificlevel taxonomy throughout its range is in need of revision. We have observed Variegated Squirrels from sea level to $1850 \mathrm{~m}$ in Costa Rica. Variegated Squirrels are often abundant at low and middle elevations, especially in disturbed areas and second growth forests and are more abundant in disturbed habitats than they are in mature forest. In all likelihood, S. variegatoides is more abundant in the country now, on the Nicoya Peninsula, and in Cabo Blanco, than it was when there was more mature forest. Variegated Squirrels are well adapted to second-growth habitats, and this squirrel can be so abundant that it is considered a serious agricultural pest (Monge and Hilje, 2006).

The distinctive subspecies Sciurus variegatoides atrirufus is restricted to the southern Nicoya Peninsula, with the subspecies $S$. $v$. dorsalis occurring throughout the remainder of the peninsula. We have observed the rich reddish brown S. variegatoides atrirufus throughout the southernmost Nicoya Peninsula; it is especially common in the southwestern sector of Reserva Natural Absoluta Cabo Blanco and near Malpaís, and in the vicinity of Curú. Two distinctive color morphs are present at Curú, although we have seen only the dark reddish brown color phase at San Miguel. The common color phase, and the only one we have observed at Cabo Blanco, is a dark, bright orange rusty both dorsally and ventrally. The ear patches are rich reddish brown. The paler color phase is an orange-yellow both dorsally and ventrally. Both color phases have a strongly developed wide, black dorsal stripe running down the back from the head to the base of the tail; in width it covers some $80 \%$ of the dorsum. Only the dark color phase was seen in the vicinity of Cóbano and this color phase does not seem to be as abundant inland as it is along the beaches.

Sciurus variegatoides is abundant in Cabo Blanco, especially in the beach strand forest along the coast. In the beach strand forest, these squirrels eat the fruits of Terminalia catappa, Muntingia calubura, Attalea butyracea, and Sterculia apetala. Fruits of Terminalia and Muntingia are especially important foods because they are available in abundance throughout the year, whereas fruits of Attalea are available primarily in the early rainy season, and are extremely abundant then.

Hunting still occurs on the peninsula, but hunters generally pursue larger game species such as White-tailed Deer and Pacas and not mammals as small as squirrels. Although the meat is eaten, the primary reason for shooting squirrels is to protect maize crops.

In the Curú area, S. variegatoides atrirufus is considered to be a pest of commercial coconuts (Monge and Hilje, 2006), and it does considerable damage to green, maturing coconuts by chewing into the husk to consume the developing "meat" and the liquid endosperm. Monge and Hilje (2006) reported that adult Variegated Squirrels feed heavily on coconuts; whereas young squirrels preferred Terminalia catappa. As part of a 12-month study of these squirrels, Monge and Hilje (2006) found that coconuts, T. catappa, malinche (Delonix regia; Fabaceae), guayaba (Psidium guajava; Myrtaceae), guácimo (Guazuma ulmifolia), Attalea butyracea, and mango (Mangifera indica; Anacardiaceae) were, in decreasing order of importance, the primary foods consumed throughout the year at their site along the coast just north of Cabo Blanco. 
3.2.3.19. Order Carnivora, Family Canidae (Coyote, Foxes, etc.), Canis latrans, Coyote; Coyote. Coyotes are found from extreme northern Alaska and northwestern Canada across most of the United States, Mexico, and Central America to western Panama. A single subspecies, Canis latrans dickeyi, is found in Costa Rica. Coyotes are continuing to expand their range in Central America; they now occur in Costa Rica's Caribbean lowlands, although they are rare there.

Coyotes were hunted in this area with rifles to protect chickens and out of fear (Castrillo, personal communication). In San Miguel, the howling of Coyotes used to be heard frequently. They are still sometimes heard, and can occasionally be seen, especially along the beach, but there seem to be fewer now than formerly. In Central America, Coyotes are a species of open areas and not closed canopy forests.

3.2.3.20. Urocyon cinereoargenteus, gray fox; Tigrillo or Zorra Gris. Gray Foxes are among the most widely distributed of the New World carnivores, being found from southern Canada across much of the United States through Mexico and Central America to northern Colombia and Venezuela. Little has been published on the distribution or ecology of Gray Foxes in the tropics. In Costa Rica, Gray Foxes are found throughout the country except for the Atlantic lowlands; on the Pacific slopes, foxes occur from sea level to the highest forested regions. The subspecies Urocyon cinereoargenteus costaricensis is found throughout the Pacific lowlands and mid- and high-elevation forests. Gray Foxes appear to be most common in altered habitats. Foxes are perhaps moderately common in the reserve as well as throughout the Nicoya Peninsula, although they are not frequently observed. They are not hunted in the region. Wessberg (1968) reported that gray foxes were present at Cabo Blanco.

3.2.3.21. Family Felidae (Jaguar, Margay, Ocelot, Puma, etc.), Leopardus pardalis, Ocelot; Manigordo or Ocelote. Ocelots are found from the southern United States along the Pacific and Caribbean coasts of Mexico through much of Central America to northern Argentina. The subspecies Leopardus pardalis mearnsi is found in Costa Rica. Ocelots occur in a variety of habitats, including dense forest, second growth, and agricultural areas, where they range elevationally from sea level to nearly $3800 \mathrm{~m}$. Leopardus pardalis is classified as a species in danger of extinction, by Costa Rica's Ministerio del Ambiente y Energía (SINAC, 2008).

Ocelots are observed only occasionally in the reserve. They were not hunted to any extent in the Cabo Blanco region and seemingly have been rare for several decades (Castrillo, personal communication). Wessberg wrote in the early 1960s that Ocelots were endangered because of the rapid destruction of habitat.

3.2.3.22. Leopardus wiedii, Margay; Caucél. Margays originally were found from the southwestern United States through Central and South America to northern Argentina. The subspecies Leopardus wiedii nicaraguae formerly occurred throughout Costa Rica from sea level to the higher elevations. Margays are classified as a species in danger of extinction, by Costa Rica's Ministerio del Ambiente y Energía (SINAC, 2008). Margays are seen only occasionally in the Reserva Natural Absoluta Cabo Blanco and must be considered rare in the region.

3.2.3.23. Panthera onca, jaguar; Tigre. Jaguars were once found as far north as the Grand Canyon and California in the United States, through Mexico, all of Central America, and much of South America to northern Argentina. In Costa Rica, the subspecies Panthera onca centralis occurred from sea level to the highest forested elevations, although the numbers and distribution have been greatly reduced by hunting pressure and habitat destruction. Panthera onca is classified as a species in danger of extinction, by Costa Rica's Ministerio del Ambiente y Energía (SINAC, 2008).

Jaguars were once common on the peninsula. In 1968, Wessberg (p. 15) wrote that Jaguars were present in the reserve; however, he later wrote that they were extinct in the Cabo Blanco region. In recent years, however, Jaguars have been seen just outside the reserve, but only occasionally, and the species must be considered extremely rare, although present, in the region. An adult Jaguar and its cub lived at the north edge of the reserve and in the adjacent pasture areas of Malpaís for several years during the 1990 s, where it occasionally preyed upon cattle. It disappeared in the late 1990s or early 2000s and is believed to have been killed. Jaguars were hunted both by day and by night using dogs; they were shot because they preyed upon livestock including pigs.

3.2.3.24. Puma concolor, Puma; Puma or León de Montaña. The Puma was the most widely distributed mammal in the New World, originally occurring from Alaska across most of North America and throughout Central America and South America to Tierra del Fuego. The subspecies Puma concolor costaricensis was distributed throughout Costa Rica and was found in a wide variety of habitats from sea level to $3300 \mathrm{~m}$. Because of hunting, Pumas now occur in reduced numbers in Costa Rica, but where they are protected and sufficient area is set aside for a prey base, Pumas are present in significant numbers. The Puma is classified as a species in danger of extinction, by Costa Rica's Ministerio del Ambiente y Energía (SINAC, 2008).

Pumas currently occur in Reserva Natural Absoluta Cabo Blanco, but are seen infrequently, and their numbers are probably lower than in the past (Castrillo, personal communication). They may come and go from the reserve as part of their regular movements through their home ranges. Wessberg (1968) wrote that Pumas were present in the reserve in the 1960s.

3.2.3.25. Puma yagouaroundi, Jaguarundi; León Breñero or Gatillo de Monte. Jaguarundis originally ranged from the southwestern United States through Central America to northern Argentina. The subspecies Puma yagouaroundi panamensis is distributed throughout Costa Rica in suitable habitat along both coasts to $2000 \mathrm{~m}$ in elevation. Jaguarundis are the most diurnal of the Neotropical cats, and the most adaptable, occurring in primary and secondary forests as well as in pastures. Jaguarundis are classified as a species in danger of extinction, by Costa Rica's Ministerio del Ambiente y Energía (SINAC, 2008). Although they are seen occasionally in the San Miguel sector, Jaguarundis are rare in the region.

3.2.3.26. Family Mephitidae (Skunks), Conepatus semistriatus, striped hog-nosed Skunk; Zorro Hediondo. Striped Hog-nosed Skunks are found from Veracruz, Mexico, to Colombia and Peru. The Costa Rican subspecies, Conepatus semistriatus trichurus, is probably found throughout the country but is observed infrequently and little is known of it. Striped Hog-Nosed Skunks, although not frequently observed at Cabo Blanco, are present in the reserve as well as throughout the Nicoya Peninsula.

3.2.3.27. Spilogale angustifrons, southern spotted skunk; Zorro Hediondo. The Southern Spotted Skunk is a Middle American endemic occurring from central Mexico and Belize to Costa Rica. The distribution of spotted skunks in Costa Rica is quite poorly understood. We have observed spotted skunks at Cabo Blanco, Parque Nacional Palo Verde, Playa Naranjo, and Playas del Coco. Spotted skunks are generally uncommon; however, we have found them to be relatively common along the Pacific coast of Costa Rica. 
Spotted skunks are observed regularly at Cabo Blanco. In the vicinity of the San Miguel station, they have become habituated to humans and can regularly be observed foraging in the coastal lowlands after sundown. If the observer is quiet, one can follow the skunk, watching it forage for insects and crabs. In April 2003, we observed a young spotted skunk attempting to feed upon a large harlequin land crab. The half grown skunk struggled to subdue the crab, but the crab escaped unharmed.

3.2.3.28. Family Mustelidae (Otters, Tayra, Weasels, etc.), Eira barbara, Tayra; Gato de Monte or Cholomuco. Tayras are found from Sinaloa and Tamaulipas, Mexico, south to northern Argentina. Two subspecies are known from Costa Rica-Eira barbara inserta from northern and western Costa Rica and E. b. biologiae from the southern and eastern part of the country. Tayras are found from sea level to high-elevation cloud forest.

Tayras are seen occasionally at Cabo Blanco, but there is no information concerning their abundance or biology there.

3.2.3.29. Lontra longicaudis, Neotropical River Otter; Perro de Agua or Nutria. Neotropical River Otters are found from northwestern Mexico south through Central America to Peru and Uruguay, although they are rare in much of this range, as is also true for Costa Rica. All otters in Costa Rica are now considered to belong to the subspecies Lontra longicaudis annectens, although the lack of specimens has hindered a critical systematic review.

Otters are observed from time to time along the Quebrada San Miguel. On two separate occasions, M. Lieberman watched otters splashing, cavorting, and feeding in a shallow pool around $40 \mathrm{~m}$ upstream from where the Quebrada San Miguel enters the ocean. Other park guards have on occasion seen otters, singly or in pairs, hunting freshwater shrimp underwater or simply frolicking energetically in the same area (Gómez, personal communication). Otters are very wary animals; in every case when observed they disappeared quickly. On this basis, otters may in fact be more abundant than suggested by the number of direct sightings.

3.2.3.30. Mustela frenata, Long-tailed Weasel; Comadreja. Longtailed Weasels are found from southern Canada through Central America to northern South America and along the Andes south to Bolivia. Although the populations from throughout this vast region were considered to belong to a single species by Hall (1951), we believe that they represent a species complex of several species. The subspecies Mustela frenata costaricensis was described from San José, Costa Rica, and is now considered the subspecies that occurs throughout the country, although Timm notes considerable variation in this species in Costa Rica.

Long-tailed Weasels are common in the reserve as well as throughout the Nicoya Peninsula, although not frequently observed.

3.2.3.31. Family Procyonidae (Coatis, Kinkajous, and Raccoons, etc.), Nasua narica, White-nosed Coati; Pizote. Northern or White-nosed Coatis range from the southwestern United States through much of Central America to northwestern Colombia. Coatis are extremely adaptable and are found in a wide array of habitats, including deserts, tropical wet forests, and tropical dry forests. In Costa Rica, the subspecies Nasua narica narica is found from sea level to at least $3500 \mathrm{~m}$.

Coatis are common in the reserve today and also were abundant in the 1950s. They were hunted occasionally in the past, and were killed to protect the maize fields. Wessberg was charmed by their antics, and wrote in 1955 that coatis ("näsbjörnen") were a common sight, climbing lianas and trees, rooting among fallen palm fronds, and generally ignoring his presence as they fed on palm fruits (Skog, personal communication).

3.2.3.32. Potos flavus, Kinkajou; Martilla. Kinkajous are found from tropical Mexico through Central America to the Mato Grosso of Brazil. The subspecies Potos flavus chiriquensis occurs throughout Central America to the Darién of Panama. In Costa Rica, Kinkajous are found from sea level to the highest elevations where forest occurs.

In this area, Kinkajous were hunted for their skins, which were prized for making the soft "grupero" or crupper for saddles (Castrillo, personal communication); the crupper is a long leather loop that attaches to the back of the traditional colonial roping saddle and passes under the tail of the horse to prevent the saddle from slipping forward. Kinkajous are often seen and heard in the reserve; at night their wailing vocalizations and barks are commonly heard from the trees.

3.2.3.33. Procyon lotor, Northern Raccoon; Mapachín. Northern Raccoons are found throughout North America and Central America from southern Canada to eastern Panama, with the exception of the most arid deserts and high elevations. Two subspecies of Procyon lotor are found in Costa Rica, P. l. crassidens, which occurs throughout most fon of the country, including the Nicoya Peninsula, and $P$. $l$. pumilus, which occurs near the Panamanian border. Raccoons occur from sea level to middle elevations.

Northern Raccoons are very common all along the Pacific coast of Costa Rica and are one of the most frequently seen mammals at Cabo Blanco. Raccoon abundance both inside and outside the reserve seems to be increasing. They can be seen after dark in San Miguel foraging along the shore and in tide pools. They are often observed feeding on harlequin land crabs. When large harlequin crabs are abundant, the raccoons capture them, break off both the left and right claws, consume the meat in the claws, and release the crabs otherwise unharmed. Empty carapaces of harlequin crabs litter the forest floor during much of year, for which raccoons and coatis are likely responsible. Raccoons are pests if food is left unattended and are frequent marauders of planted crops. Raccoons in this region were hunted to protect maize fields (Castrillo, personal communication).

3.2.3.34. Order Perissodactyla, Family Tapiridae (Tapirs), Tapirus bairdii, Baird's Tapir; Danta. Baird's Tapir originally was found from southeastern Mexico's Isthmus of Tehuantepec south throughout Central America to the western slopes of the Andes in Colombia and Ecuador. Tapirs probably were common throughout Costa Rica prior to the introduction of firearms by the Spanish. In Costa Rica, tapirs occur from sea level to $3800 \mathrm{~m}$ where adequate habitat exists and where they are protected from hunting. They're hunted because the meat is sought after. Tapirus bairdii is classified as a species in danger of extinction, by Costa Rica's Ministerio del Ambiente y Energía (SINAC, 2008). No subspecies of Baird's Tapir are recognized.

As recently as the 1940s, tapirs were seen regularly in what is now Cabo Blanco, and local people regularly included tapir meat in their diet (Castrillo and Briceño, personal communication). The last tapirs seem to have disappeared from Cabo Blanco shortly before the reserve was established. Wessberg wrote in 1955 that tapirs were still present, but that they were being hunted with shotguns and .22 caliber rifles, and he predicted they would soon be exterminated. As he was attempting to raise money to purchase the land for the reserve in the early 1960s, he wrote to friends saying that the Jaguars and tapirs were already extinct in the area (Wallace, 1992). Despite his years of living on the Nicoya Peninsula, he had not seen tapirs in the wild himself. 
3.2.3.35. Order Artiodactyla, Family Cervidae (Deer), Mazama temama, Central American Red Brocket Deer; Cabrito or Cabro de Monte. The Central American Red Brocket Deer occurs from central Mexico through Central America to Panama and western Colombia. The species name now recognized for the Central American brocket deer is Mazama temama; until recently, M. americana was used for all of the red brocket deer, but that name is now restricted to the South American populations. Brocket deer were once found throughout much of Costa Rica.

Although there are no verified specimens of brocket deer from the Nicoya Peninsula, nor are there references in the scientific literature, we suspect that they were present historically but have now been extirpated from the entire peninsula. Wessberg reported that brocket deer were abundant at Cabo Blanco, but with no recent observations or records we can only assume that it has now been extirpated.

3.2.3.36. Odocoileus virginianus, White-tailed Deer; Venado Cola Blanca. In Costa Rica, White-tailed Deer are found from sea level to at least $1300 \mathrm{~m}$. Two subspecies of White-tailed Deer occur in the country-Odocoileus virginianus chiriquensis in the southwest and $O$. v. truei throughout the rest of the country, including the Nicoya Peninsula.

White-tailed Deer are now common throughout the reserve and especially so in the San Miguel sector. Deer feed on the fruits of guácimo and of the royal palm, among other species. Their main predators are Pumas and Coyotes.

Deer have been and continue to be hunted for meat and for sport throughout the Nicoya Peninsula, as they have throughout the Pacific lowlands. The meat is dried, grilled, or made into soup. In the Cabo Blanco area, some poaching continues, and deer are shot along the shore when the animals emerge from the forest to drink saltwater from tide pools, or are shot in pastures where they are foraging. Both males and females are hunted, and dogs are used for hunting deer during the day. Deer also have been killed because of the damage they cause to vegetable gardens and bean fields. Illegal hunting of deer remains a concern, and White-tailed Deer are a preferred game species. In the 1930s, large hunting parties were organized in which well-to-do Costa Ricans came on holiday from the capital, San José, to the Nicoya Peninsula to hunt deer on horseback (Diego Gómez, personal communication).

In 1968, Wessberg wrote that (p. 15) "There are plenty of deer, one sees them on nearly every excursion...." Lippold (1990) reported that deer were shot by sport and subsistence hunters at Cabo Blanco, who shot them along the reserve's borders when the deer were foraging in pastures.

Deer hides were formerly used in fine saddlemaking; the tanned leather, which is of excellent quality and softness, was laid on the seat of the saddle. Today, however, the skin is quickly discarded by poachers so as to avoid detection by authorities.

3.2.3.37. Family Tayassuidae (Peccaries), Pecari tajacu, Collared Peccary, Saino. Collared Peccaries are found from the southwestern United States throughout Central America and tropical South America to Santiago del Estero in northern Argentina. One subspecies, Pecari tajacu crusnigrum, is found in Costa Rica from sea level to about $3000 \mathrm{~m}$. Collared Peccaries have been given complete protection throughout Costa Rica, as a threatened species, although they are still taken by hunters in some rural areas.

Although they were not seen in San Miguel for decades, Collared Peccaries were once again sighted around 2003 (Gómez, personal communication), and are now being observed with increasing frequency. In San Miguel, peccaries are seen individually or in pairs; farther inland, around Maven, larger groups have been seen during 2008 (Palacios, personal communication). In addition to the visual confirmation of their presence, observers note their grunts, their distinctive musky odor, and their hoof prints and rooting marks in the ground. Collared Peccaries were abundant and were regularly hunted in the region in the 1930s and 1940s (Aviléz, personal communication).

3.2.3.38. Tayassu pecari, White-lipped Peccary; Chancho de Monte. White-lipped Peccaries once occurred in lowland tropical forests from Veracruz and Oaxaca in southern Mexico through Central America and much of tropical South America to northern Argentina. One subspecies, Tayassu pecari spiradens, was found in Costa Rica from sea level to at least $1500 \mathrm{~m}$. The White-lipped Peccary is classified as a species in danger of extinction, by Costa Rica's Ministerio del Ambiente y Energía (SINAC, 2008).

Local residents on the southern Nicoya Peninsula recall the presence of White-lipped Peccaries in the 1940s and earlier, and note that both Collared Peccaries and White-lipped Peccaries were commonly hunted at that time in the Cabo Blanco area (Briceño, personal communication). Wessberg wrote in 1955 that hunting of wild pigs ("vildsvin") in the area was rampant, and predicted that the species would soon be wiped out; he noted that local residents still spoke of the great herds of peccaries, many-hundred strong, that were common in the area in the 1940s, although he had not seen this personally (Skog, personal communication). Whitelipped Peccaries apparently had disappeared by the time the reserve was established.

\subsubsection{Introduced species}

Two genera of Old World mice and rats are now widely distributed throughout Central America, the original introductions having occurred with the earliest Spanish ships in the 1500s. The introduced House Mouse (ratón in Costa Rica), Mus musculus, was perhaps found originally through much of central Asia from the Mediterranean to China; it is now a commensal that has followed humans throughout much of the world and is widely distributed in Costa Rica. We have found no evidence of M. musculus occurring in Cabo Blanco, although we must assume that individuals have occasionally made it into the reserve.

Rats of the genus Rattus are widely introduced commensals of humans. A population of Rattus now occurs on Isla Cabo Blanco, a rocky islet located approximately $1 \mathrm{~km}$ south of the tip of the Peninsula. Isla Cabo Blanco is home to large breeding populations of brown boobies (Sula leucogaster) and magnificent frigatebirds (Fregata magnificens) and is an important roosting site for other seabirds. The rats seemingly feed on booby eggs and nestlings. Rats may have reached the island at several times and in several ways over the years. Fishing boats and other vessels have occasionally run aground on the treacherous rocks that surround the island. For several decades through the 1990s, small boats made regular visits to the island for routine maintenance of a light and communications tower, in each case beaching the craft in order to land personnel, supplies, camping gear, and food. M. Lieberman examined one poorly preserved specimen of a rat from the island and thought it might represent Rattus norvegicus, the Norway Rat. In Central America, the common species seen is the Black Rat or roof rat, Rattus rattus, and it is possible, although unlikely, that both species occur on the island.

It is our experience that neither Mus or Rattus can establish populations in expanses of primary vegetation in Costa Rica. They are commensals of humans and are important economic pests around buildings and in crops, but are unable to sustain populations in natural habitats, and, in the 45 -year old regenerating forests of Cabo Blanco. 


\section{Discussion}

4.1. Structure of mammalian communities, and implications for management and future research

We have attempted to reconstruct the history of hunting and land use over the past 100 years in the area that is now encompassed by Reserva Natural Absoluta Cabo Blanco. Data compiled include our own observations, those taken from interviews with long-time residents of the area, notes of colleagues working with tropical biology courses in the reserve over the past decade, as well as historical documents, some of which were provided by Nicolas Wessberg and Karen Mogensen, founders of the reserve. Our combined efforts are largely qualitative but they now allow us to formulate testable hypotheses about the structure of the mammalian community at Cabo Blanco and also to contribute to the wider inquiry regarding mammalian community structure in disturbed and regenerating forests throughout the Neotropics. We also speculate on the future of this area under conditions of continued isolation from other forest reserves versus the potential impact that a forested corridor connected to other larger forested areas in central Costa Rica would have. Finally, we comment on the role of expanded settlement and tourism in areas around the reserve and the contrast presented by a regenerating forest in a degenerating matrix.

\subsection{Structure of mammalian communities}

Terborgh (1992), writing about Amazonian rainforests, predicted a series of indirect and direct effects of forest fragmentation, having an escalating scale of impact upon forest structure and community structure, including the "empty forest" or defaunation scenario seen at some other Neotropical sites (Redford, 1992; Dirzo and Miranda, 1990). Although pressures from forest destruction and hunting have been felt strongly at Cabo Blanco, they have not been severe enough to trigger extreme system collapses such as the loss of top carnivores. Further support of our view that Cabo Blanco is not currently a drastically unbalanced system comes from our multiple-year bat inventory (Timm and McClearn, 2007)-we found the bat community to be complex, species-rich, and possessing most of the characteristics of an intact assemblage: presence of rare species, abundance of carnivorous phyllostomids, and lack of any single dominant species.

We generate here a set of hypotheses about the mammal community and forest composition at Cabo Blanco in three different categories: (1) role of top predators, (2) effects of different categories of mammalian seed predators and seed dispersers, and (3) transition in the fauna and vegetation from the beach zone to the forest interior.

Role of top carnivores-An evaluation of the ecological role of top carnivores at Cabo Blanco will require an analysis of the diets of carnivores in the context of the prey base available. Based on analysis of bone and hair fragments in scats, it appears that large cats such as Jaguars and Pumas have considerable overlap in their diets where they coexist in Paraguay (Taber et al., 1997) and Mexico (Núñez et al., 2000). Yet diets may be very different in different forests-Jaguars rely on armadillos at a site in Belize (Rabinowitz and Nottingham, 1986) and on White-tailed Deer at a site in Mexico (Núñez et al., 2000).

At Cabo Blanco, Pumas are not competing for prey with Jaguars because Jaguars have been effectively extirpated from the region, and we might predict either (a) that Pumas will consume prey in relation to its availability (leading to the consumption of more rodents) or (b) that certain larger prey items (such as the deer and peccaries) will be preferentially consumed. A long-term dietary study of carnivore populations would reveal also whether the diets of the Pumas and other carnivores (Tayras, Coyotes, and foxes) were changing as the forest structure and prey base changed over decades.

Seed predators and seed dispersers-Seed dispersal and seed predation by vertebrates is considered to be one of the major factors structuring Neotropical plant communities (Howe and Miriti, 2004). While our focus here is on mammals, it is clear that birds are also significant agents of seed dispersal and seed predation. Disturbances such as hunting and forest fragmentation that affect mammal populations can potentially have profound secondary effects on the vegetation structure of the forest (Laurance and Bierregaard, 1997; Wright, 2003; Stoner et al., 2007a,b). The effects of mammal populations on seed dispersal and seed predation can be evaluated in several ways, including comparisons of seed and seedling survival where different levels of hunting have occurred, or exclosure experiments that eliminate different size categories of seed or seedling predators. When seeds are protected from mammalian access, there may result a secondary effect of increased seedling recruitment (Dirzo and Miranda, 1991; Wright et al., 1999) or decreased seedling recruitment (Asquith et al., 1997; Roldan and Simonetti, 2001), depending upon the relative importance of seed predation versus seed dispersal by the excluded mammals (Brewer et al., 1997; Beckman and Muller-Landau, 2007).

All of the major categories of mammalian seed predators and seed dispersers are present at Cabo Blanco, including small rodents (mice, rats, and squirrels), medium-sized mammals (Virginia Opossums, agoutis, Pacas, coatis, Kinkajous, and foxes), artiodactyls (peccaries and deer), flying mammals (bats), and two species of monkeys. Any number of studies could be designed to test the plethora of hypotheses in the seed dispersal literature. Below, we outline two possible studies on the role of Cabo Blanco mammals in seed and seedling survival.

1. Tracking the fates of Brosimum seeds and seedlings-Brosimum trees produce large fruits that are attractive to a wide range of mammalian seed predators. At Los Tuxtlas (Veracruz, Mexico), where midsized and large terrestrial vertebrates are dramatically reduced in number, Brosimum alicastrum seedlings create dense carpets beneath the parent tree (Dirzo and Miranda, 1990). At the other extreme, at Parque Nacional Corcovado on southwestern Costa Rica's Osa Peninsula, where mammalian seed predators are abundant, Brosimum costaricanum seedlings in a natural regeneration study were encountered only in exclosures that had been protected from both peccaries and small rodents (DeMattia et al., 2004, 2006). Adult Brosimum alicastrum and B. costaricanum are both present at Cabo Blanco, but the fates of their seeds and seedlings have not been studied. We predict that seed and seedling survival patterns in exposed areas beneath parent trees would lie somewhere between those seen in the defaunated forest of Los Tuxtlas (with carpets of seedlings) and in the largely intact old-growth forest at Corcovado (with no seedlings in exposed areas). We also predict that the fates of seeds in the crab zone near the shore would differ from those in the forest where more rodents live a kilometer from shore.

2. Evaluation of monkey biomass in relation to forest fruit production-many mammalian seed dispersal and seed predation studies have focused on the fate of seeds once the fruits fall to the ground. Removal of fruits from the trees can be more difficult to assess, but there have been several important studies on the effects of monkeys on fruit dispersal in Neotropical forests (Chapman and Onderdonk, 1998; Moura and McConkey, 2007). If there is indeed a positive relation between overall fruit 
production and the primate biomass in Neotropical forests that have had little or no hunting pressure (Stevenson, 2000), then the values of these indices could be determined at Cabo Blanco to evaluate whether primate biomass had recovered in the past 45 years to match the level of fruit production in the forest. A value for this relation that was not significantly displaced below the regression line for other Neotropical forests would indicate recovery of Cabo Blanco monkey biomass, despite the elimination of the frugivorous spider monkey. As Kinkajous, coatis, and parrots are significant fruit consumers also, this technique should be coupled with primate surveys, as well as with surveys of the climbing procyonids, to accurately assess mammalian frugivores' impacts on fruit consumption, dispersal, and seed survival.

Transition between shore and forest interior-On both Costa Rica's Nicoya and Osa peninsulas, there are pronounced differences along the shore and $1 \mathrm{~km}$ inland in terms of vegetation, microhabitat variables, and the vertebrate and invertebrate fauna. In some years, land crabs and hermit crabs (Coenobita compressus, Paguroidea) are responsible for prodigious amounts of seed predation, seed dispersal, and herbivory along the low-lying coastal strip (Sherman, 2002; Lindquist and Carroll, 2004). At about 600-800 $\mathrm{m}$ from shore, where the ancient terrace sea level is higher in elevation, the crabs become significantly less common, and small mammal abundances increase (Timm and McClearn, pers. obs.). Although it has been established that land crabs will kill small seedlings of plants typical of the noncrab zone (Sherman, 2002), it is not known how the feeding activities of crabs and rodents are affecting the plant community. We hypothesize that crabs and rodents differentially influence the vegetation in the two distinct zones. This hypothesis could be tested by placing seed trays and seedling arrays containing representatives from both areas across the transition zone from crab-dominated to rodent-dominated areas. We predict that the seeds and seedlings chosen (removed, eaten, or buried) in the crab zone will be different from those chosen in the rodent zone, with a mixed effect in the transition zone between crab and rodent dominance. We also hypothesize that the large numbers of crabs are responsible for the low numbers of rodents seen close to the shore, either indirectly through competition for seeds or directly through predation upon young rodents in the nest.

\subsection{Corridors, matrix, and connectivity}

The current status of Cabo Blanco's mammal populations reflect both reproduction of the remnant animals and dispersal of new individuals into the reserve from outside the reserve's boundaries. Likely routes of dispersal into the reserve include the forested riverways and access provided by high quality matrix habitat. Conservationists are concerned, however, that the relative isolation of small-protected areas such as Reserva Natural Absoluta Cabo Blanco may threaten the long-term health of such a system. The interconnection of all reserves in Costa Rica through the creation of biological corridors is being urged (Rojas and Chavarría, 2005). Conservationists are increasingly focusing on the quality of the matrix habitat as an important element in maintaining the health of a forest fragment (Hughes et al., 2002; Horner-Devine et al., 2003; Murphy and Lovett-Doust, 2004; Debinski, 2006; Laurance, 2008).

The idea of maintaining connectivity of reserves and fragments through biological corridors and high quality matrix seems inherently logical and good (Hilty et al., 2006). Animals and plants should have more opportunities to move among patches, thus maintaining genetic diversity in their populations and lessening the likelihood of the random extinction of small isolated populations (Beier and Noss, 1998; Mech and Hallett,
2001; Lemckert et al., 2005). Corridors may promote not only the biodiversity of plants and animals, but also their biological interactions such as pollination and seed dispersal (Tewksbury et al., 2002; Kirchner et al., 2003). There have been some warnings from conservation biologists about the potential negative effects of corridors, such as the spread of infectious diseases, invasive alien species, and an increase in predators along corridor pathways (Simberloff et al., 1992; Hilty and Merenlender, 2004; Weldon, 2006), but the balance of opinion currently favors the creation of corridors as a conservation and management tool. Furthermore, connectivity is increasingly a component of decisions about establishing reserves or developing an area for economic use (Puth and Wilson, 2001; Dzialak et al., 2005).

Until recently, there have been very few empirical studies of the effects of corridors on tropical vertebrate biodiversity. The abundance of howler monkeys in forest patches in Chiapas, Mexico, was positively correlated with the presence of corridors and also with canopy height (Anzures-Dadda and Manson, 2007). Corridors of both mature forest and scrubby second growth can maintain populations of understory birds in Chile (Castellón and Sieving, 2006). Clearly the responses of Jaguars, bats, and small rodents will be very different in the face of forest fragmentation, corridor creation, and matrix degradation. An understanding of the genetic structure of these populations would be useful in evaluating the status of their metapopulations and estimating their risk of extinction.

Using data on land cover change derived from aerial photography over the period from 1960 to 1997, Sánchez-Azofeifa et al. (2003) documented that the habitat integrity within Costa Rica's protected areas and national parks, including Cabo Blanco, was maintained over the study period. The rate of deforestation outside the protected areas, however, has been fairly high over the 40 -year period. The quality of buffer zones has decreased and parks have become more isolated on a regional scale. The authors stressed the importance of linking conservation areas to each other via biological corridors in order to create a functional network of conservation areas and to ensure preservation of the country's biodiversity.

\subsection{Tourism and educational use of the reserve}

Tourism is one of the top industries of Costa Rica. The tourism boom expanded rapidly in the country after President Óscar Arias Sánchez was awarded the Nobel Peace Prize in 1987. Even smaller, more remote reserves such as Cabo Blanco are important ecotourism sites. From 1992 through mid-1996, the Cabuya sector of Cabo Blanco saw 38,412 visitors, of which 30,040 (78.2\%) were foreign visitors and 8372 (21.8\%) were Costa Ricans (Evans, 1999).

In 1997, the San Miguel sector of the reserve was opened, in part, for small numbers of educational and research groups, and today the level of use remains low, with fewer than 250-300 overnight visitors per year. In addition to overnight visitors, school children from the surrounding communities are invited on a regular basis to visit the San Miguel sector for day-visits, taking part in educational programs, walking short distances on the trails, and learning about the park and its history.

The uncontrolled growth of tourism in the nearby town of Malpaís and the surrounding area has led to a rapid alteration of the landscape outside the reserve and to a dramatic increase in the number of residents and visitors to the area. Today there are several dozen hotels, a newly built shopping center, and burgeoning commercial and real estate development. Hotel occupancy is highest during the dry season, when water is scarce. Excessive use of water resources, production of sewage and 
garbage, vehicle traffic, and light and noise pollution are issues currently facing the communities around the reserve.

The growth and development in Malpaís have placed additional pressures on park personnel in the San Miguel sector, especially during the December-January high season and around Easter vacation, when tourists occasionally ignore posted signs and attempt to illegally enter the reserve. The maintenance of San Miguel's current status as a site dedicated exclusively to limited, low-impact educational and scientific purposes is vital to its role in protecting wildlife, and the reserve remains strongly committed to this goal.

\subsection{Implications for management}

The southern part of the Nicoya Peninsula is one of the most poorly studied regions in all of Costa Rica, and one that has been impacted by humans for centuries. The regeneration of the forest in San Miguel, following the establishment of the Cabo Blanco reserve in 1963, has been rapid, as has been the return of previously hunted wildlife. A matter of concern, however, is that the pressures on the region's forests and wildlife are changing and intensifying in some ways. The protection of these forest jewels will require new and in some cases untested methods of intervention.

The principal factors that have had a negative effect on wildlife species in this area in the past were hunting, loss of habitat to agriculture and cattle ranching, and occasional large disturbances such as tornadoes, all of which might have long-lasting effects on mammal populations (Klinger, 2006). Current pressures include degradation of matrix habitat, more intensive urbanization and tourism, and the ongoing but unknown effects of the isolation of mammal populations.

Long-term maintenance of wildlife populations demands that the area of habitat, the availability of resources, and gene flow with other subpopulations be adequate. Cabo Blanco is isolated from other large tracts of protected habitat, but there are other nearby reserves with substantial areas of protected forest and wildlife at Curú, near Paquera to the east of Cabo Blanco; Reserva Karen Mogensen, in the hills near Jicarál; Río Bongo on the Pacific coast north of Malpaís; and a number of smaller reserves and forest patches.

Genetic studies indicate a high current level of genetic variability within the Cabo Blanco tree populations, especially those with wind-dispersed seeds (Case and Hamrick, 2001). We assume that the genetic heterogeneity in Cabo Blanco's bat species is likewise high, although that assumption has yet to be tested. The level of genetic diversity of other mammal species from different trophic levels should be evaluated as well.

The ideal program for maintaining mammalian biodiversity and ecosystem health at Cabo Blanco will consist of a combination of actions. These included continued protection in the reserve, preservation of riverine natural corridors, establishment of new corridors among fragments, continued efforts to curb the loss of habitat outside of the reserve, and possibly restocking of wildlife in some areas. These interventions will reduce the detrimental influence of the degraded matrix and assure the value of the regenerating forest and the mammal populations within the forest.

\section{Acknowledgments}

The Ministerio del Ambiente y Energía (MINAE) and Sistema Nacional de Areas de Conservación (SINAC) provided us the opportunity to work in Reserva Natural Absoluta Cabo Blanco; we especially thank reserve Administrator Lara Anderson Rana for her support and cooperation and Javier Guevara S. for facilitating our research permits.
Several long-time residents of the area freely shared their knowledge with us. We are extremely grateful to Guadalupe Aviléz, Felipe Briceño Herrera, Carlos Castrillo Castrillo, Luz Marina Gómez Gómez, and Elias Nuñez Garcia for sharing with us the history of wildlife use and land management of the region, which greatly contributed to our understanding of the area's ecology. Dedicated administrators have played a vital role throughout the years in gathering data and working to ensure the protection of the Reserve and its resources, including, in recent years, Lara Anderson Rana, Stanley Arguedas Mora, Oscar Castillo Rodríguez, Luis Mena Aguilar, Gonzalo Ramírez, and Emel Rodríguez Paniagua. Eva Friberg Skog, the godchild of Wessberg and Mogensen, kindly made available a series of unpublished letters written in the 1950s and 1960s by Wessberg to friends in Sweden. Erin S. Lindquist and Fabricio Camacho Céspedes generously shared their observations on mammals, food plants, and forest structure. The Organization for Tropical Studies provided logistic support for this project. Reference specimens of selected taxa are deposited in the mammal collection of the Museo Nacional de Costa Rica, San José; Universidad de Costa Rica, San José; and University of Kansas.

We thank Barbara Clauson, Richard K. LaVal, Ronald H. Pine, Arturo Sánchez-Azofeifa, and Kathy Stoner for their extremely valuable suggestions on earlier drafts of this manuscript, and Hayley Lanier and Sean Maher for assistance in producing the map used as Fig. 1.

\section{References}

Anzures-Dadda, A. Manson, R.H., 2007. Patch- and landscape-scale effects on howler monkey distribution and abundance in rainforest fragments. Animal Conservation 10, 69-76.

Asquith, N.M., Wright, S.J., Clauss, M.J., 1997. Does mammal community composition control recruitment in Neotropical forests? Evidence from Panama. Ecology $78,941-946$

Beckman, N.G., Muller-Landau, H.C., 2007. Differential effects of hunting on predispersal seed predation and primary and secondary seed removal of two Neotropical tree species. Biotropica 39, 328-339.

Beier, P., Noss, R.F., 1998. Do habitat corridors provide connectivity? Conservation Biology 12, 1241-1252.

Boza, M.A., 2006. Costa Rica: Parques nacionales, National parks. Incafo, San José, Costa Rica, 224 pp.

Boza, M.A., Mendoza, R., 1981. The National Parks of Costa Rica. INCAFO, Madrid, $310 \mathrm{pp}$.

Brewer, S.W., Rejmanek, M., Johnstone, E.E., Caro, T.M., 1997. Top-down control in tropical forests. Biotropica 29, 364-367.

Bullock, S.H., Mooney, H.A., Medina, E. (Eds.), 1995. Seasonally Dry Tropical Forests. Cambridge University Press, Cambridge, p. 450.

Camacho Céspedes, F., Lindquist, E.S., Knight, M.V., Illustrator, 2007. Árboles comunes de la Reserva Natural Absoluta Cabo Blanco, Costa Rica: Common trees of Cabo Blanco Absolute Nature Reserve. Instituto Nacional de Biodiversidad (INBio), Santo Domingo de Heredia, Costa Rica, 379 pp.

Carleton, M.D., Musser, G.G., 1995. Systematic studies of oryzomyine rodents (Muridae: Sigmodontinae): definition and distribution of Oligoryzomys vegetus (Bangs, 1902). Proceedings of the Biological Society of Washington 108, 338369.

Carrillo, E., Wong, G., Cuarón, A., 2000. Monitoring mammal populations in Costa Rican protected areas under different hunting restrictions. Conservation Biology $14,1580-1591$.

Case, A., Hamrick, J., 2001. High genetic variation but low population differentiation in Enterolobium cyclocarpum and Luehea seemannii at two Costa Rican locations. Undergraduate Honors Thesis, University of Georgia, Athens, GA.

Castellón, T.D., Sieving, K.E., 2006. An experimental test of matrix permeability and corridor use by an endemic understory bird. Conservation Biology 20,135-145.

Chapman, C.A., Onderdonk, D.A., 1998. Forests without primates: primate/plant codependency. American Journal of Primatology 45, 127-141.

Coates, A.G., 1997. The forging of Central America. In: Coates, A.G. (Ed.), Central America: A Natural and Cultural History. Yale University Press, New Haven, pp. $1-37$.

Daily, G.C., Ceballos, G., Pacheco, J., Suzán, G., Sánchez-Azofeifa, A., 2003. Countryside biogeography of neotropical mammals: conservation opportunities in agricultural landscapes of Costa Rica. Conservation Biology 17, 1814-1826.

Debinski, D.M., 2006. Forest fragmentation and matrix effects: the matrix does matter. Journal of Biogeography 33, 1791-1792.

DeMattia, E.A., Curran, L.M., Rathcke, B.J., 2004. Effects of small rodents and large mammals on tropical seeds. Ecology 85, 2161-2170. 
DeMattia, E.A., Rathcke, B.J., Curran, L.M., Aguilar, R., Vargas, O., 2006. Effects of small rodent and large mammal exclusion on seedling recruitment in Costa Rica. Biotropica 38, 196-202.

Dirzo, R., Miranda, A., 1990. Contemporary neotropical defaunation and forest structure, function, and diversity-a sequel to John Terborgh. Conservation Biology 4, 444-447.

Dirzo, R., Miranda, A., 1991. Altered patterns of herbivory and diversity in the forest understory: a case study of the possible consequences of contemporary defaunation. In: Price, P.W., Lewinsohn, T.M., Fernandes, G.W., Benson, W.W. (Eds.), Plant-Animal Interactions: Evolutionary Ecology in Tropical and Temperate Regions. Wiley, New York, pp. 273-287.

Dzialak, M.R., Lacki, M.J., Larkin, J.L., Carter, K.M., Vorisek, S., 2005. Corridors affect dispersal initiation in reintroduced peregrine falcons. Animal Conservation 8 421-430.

Evans, S., 1999. The Green Republic: A Conservation History of Costa Rica. University of Texas Press, Austin, $317 \mathrm{pp}$.

Freese, C.H., 1983. Cebus capucinus (mono cara blanca, white-faced capuchin). In: Janzen, D.H. (Ed.), Costa Rican Natural History. University of Chicago Press, Chicago, pp. 458-460.

Glander, K.E., 1980. Reproduction and population growth in free-ranging mantled howling monkeys. American Journal of Physical Anthropology 53, 25-36.

Glander, K.E., 1983. Alouatta palliata (congo, howling monkey, howler monkey). In: Janzen, D.H. (Ed.), Costa Rican Natural History. University of Chicago Press, Chicago, pp. 448-449.

Gómez, L.D., 1986. Vegetación de Costa Rica: Apuntes para una biogeografía costarricense. In: Gómez, L.D. (Ed.), Vegetación y clima de Costa Rica, vol 1Editorial Universidad Estatal a Distancia, San José, Costa Rica, pp. 1-327, +9 maps.

Gudmundson, L., 1983. Hacendados, políticos y precaristas: La ganadería y el latifundismo guanacasteco 1800-1950. Editorial Costa Rica, San José, Costa Rica, 256 pp.

Hall, E.R., 1951. American Weasels, vol. 4. University of Kansas Publications, Museum of Natural History, pp. 1-466.

Herrera, W., 1985. Clima de Costa Rica. In: Gómez, L.D. (Ed.), Vegetación y clima de Costa Rica., vol. 2Editorial Universidad Estatal a Distancia, San José, Costa Rica, pp. 1-118, +9 maps.

Herrera Sota, W., Gómez Pignataro, L.D., 1993. Mapa de unidades bióticas de Costa Rica. Escala 1:685000. INCAFO, San José, Costa Rica.

Hilje Quiros, L., 2002. Los viejos y los árboles. Instituto Nacional de Biodiversidad (INBio) Santo Domingo de Heredia, Costa Rica, 423 pp.

Hilty, J.A., Merenlender, A.M., 2004. Use of riparian corridors and vineyards by mammalian predators in Northern California. Conservation Biology 18, 126135

Hilty, J.A., Lidicker Jr., W.Z., Merenlender, A.M., 2006. Corridor Ecology: The Science and Practice of Linking Landscapes for Biodiversity Conservation. Island Press, Washington, DC, $323 \mathrm{pp}$.

Holdridge, L.R., 1967. Life zone ecology, with photographic supplement prepared by Joseph, A. Tosi, Jr., revised ed. Tropical Science Center, San José, Costa Rica, 206 pp.

Holdridge, L.R., Grenke, W.C., Hatheway, W.H., Liang, T., Tosi Jr., J.A., 1971. Forest Environments in Tropical Life Zones: A Pilot Study. Pergamon Press, New York, 747 pp.

Horner-Devine, M.C., Daily, G.C., Ehrlich, P.R., Boggs, C.L., 2003. Countryside biogeography of tropical butterflies. Conservation Biology 17, 168-177.

Howe, H.F., Miriti, M.N., 2004. When seed dispersal matters. BioScience 54, 651 660.

Hughes, J.B., Daily, G.C., Ehrlich, P.R., 2002. Conservation of tropical forest birds in countryside habitats. Ecology Letters 5, 121-129.

Incer, J., 1990. Nicaragua: Viajes, rutas y encuentros (1502-1838). Asociación Libro Libre, San José, Costa Rica, 640 pp.

Janzen, D.H., 1986. Guanacaste Nacional Park: Tropical Ecological and Cultura Restoration. Editorial Universidad Estatal a Distancia (EUNED), San José, Costa Rica, 104 pp.

Janzen, D.H., 1988. Tropical dry forests: the most endangered major tropical ecosystem. In: Wilson, E.O. (Ed.), Biodiversity. Nacional Academy Press, Washington, DC, pp. 130-137.

Joyce, A.T., 2006. Land Use Change in Costa Rica: 1966-2006, As Influenced by Social, Economic, Political, and Environmental Factors. Litografía e Imprenta LIL, S.A., San José, 272 pp.

Kirchner, F., Ferdy, J.-B., Andalo, C., Colas, B., Moret, J., 2003. Role of corridors in plan dispersal: an example with the endangered Ranunculus nodiflorus. Conservation Biology 17, 401-410.

Klinger, R., 2006. The interaction of disturbances and small mammal community dynamics in a lowland forest in Belize. Journal of Animal Ecology 75, 12271238.

Laurance, W.F., 2008. Theory meets reality: how habitat fragmentation research has transcended island biogeographic theory. Biological Conservation 141, 17311744.

Laurance, W.F., Bierregaard Jr., R.O., 1997. Tropical Forest Fragments: Ecology, Management, and Conservation of Fragmented Communities. University o Chicago Press, Chicago, 640 pp.

Lemckert, F., Brassil, T., Towerton, A., 2005. Native vegetation corridors in exotic pine plantations provide long-term habitat for frogs. Ecological Management and Restoration 6, 132-134.
Lindquist, E.S., 2003. Patterns of coastal forest composition, structure, and recruitment, Costa Rica: Functions of an environmental gradient, seed rain distribution, and crab predation pressure. Ph.D. Dissertation, University of Georgia, Athens, 188 pp.

Lindquist, E.S., Carroll, C.R., 2004. Differential seed and seedling predation by crabs: impacts on tropical coastal forest composition. Oecologia 141, 661-671.

Lippold, L.K., 1988. A census of primates in Cabo Blanco absolute nature reserve, Costa Rica. Brenesia 29, 101-105.

Lippold, L.K., 1989. A wet season census of primates at Cabo Blanco Absolute Nature Reserve, Costa Rica. Brenesia 31, 93-97.

Lippold, L.K., 1990. Primates population decline at Cabo Blanco Absolute Nature Reserve, Costa Rica. Brenesia 34, 145-152.

Marshall, J.S., Anderson, R.S., 1995. Quaternary uplift and seismic cycle deformation, Peninsula de Nicoya, Costa Rica. GSA Bulletin 107, 463-473.

Mata, A., Echeverría, J., 2004. Introduction. In: Frankie, G.W., Mata, A., Vinson, S.B. (Eds.), Biodiversity Conservation in Costa Rica: Learning the Lessons in a Seasonal Dry Forest. University of California Press, Berkeley, pp. 1-12.

Mech, S.G., Hallett, J.G., 2001. Evaluating the effectiveness of corridors: a genetic approach. Conservation Biology 15, 467-474

Mensink, M.E., Tiembersma, J., Van Wee, L.T.C., 1992. Carrying Capacity for Tourism in the Reserva Natural Absoluta Cabo Blanco, Costa Rica. Forestry Department, Wageningen Agricultural University, The Netherlands.

Molina, I., Palmer, S., 2000. The History of Costa Rica. Editorial de la Universidad de Costa Rica, San José, Costa Rica, 174 pp.

Monge, J., Hilje, L., 2006. Hábitos alimenticios de la ardilla Sciurus variegatoides (Rodentia: Sciuridae) en la Península de Nicoya, Costa Rica. Revista Biología Tropical 54, 681-686.

Moura, A.C. de A., McConkey, K.R., 2007. The capuchin, the howler, and the caatinga: seed dispersal by monkeys in a threatened Brazilian forest. American Journal of Primatology 69, 220-226.

Murphy, H.T., Lovett-Doust, J., 2004. Context and connectivity in plant metapopulations and landscape mosaics: does the matrix matter? Oikos 105, 3-14.

Murphy, P.G., Lugo, A.E., 1986. Ecology of tropical dry forest. Annual Review of Ecology and Systematics 17, 67-88.

Musser, G.G., Carleton, M.D., 2005. Superfamily Muroidea. In: Wilson, D.E., Reeder D.M. (Eds.), Mammal Species of the World: A Taxonomic and Geographic Reference, 3rd ed., vol. 2. Johns Hopkins University Press, Baltimore, pp. 8941600

Núñez, R., Miller, B., Lindzey, F., 2000. Food habits of jaguars and pumas in Jalisco Mexico. Journal of Zoology (London) 252, 373-379.

Puth, L.M., Wilson, K.A., 2001. Boundaries and corridors as a continuum of ecological flow control: lessons from rivers and streams. Conservation Biology 15, 21-30.

Quesada, M., Stoner, K.E., 2004. Threats to the conservation of tropical dry forest in Costa Rica. In: Frankie, G.W., Mata, A., Vinson, S.B. (Eds.), Biodiversity Conservation in Costa Rica: Learning the Lessons in a Seasonal Dry Forest. University of California Press, Berkeley, pp. 266-280.

Quesada López-Calleja, R., 1980. Costa Rica: La frontera sur de Mesoamérica, 2nd ed. Instituto Costarricense de Turismo, Madrid, Spain, 288 pp.

Rabinowitz, A.R., Nottingham, B.G., 1986. Ecology and behaviour of the jaguar (Panthera onca) in Belize, Central America. Journal of Zoology (London) 210, $149-159$.

Redford, K.H., 1992. The empty forest. BioScience 42, 412-422.

Rodríguez, J., Chinchilla, F.A., 1996. Lista de mamíferos de Costa Rica. Revista de Biología Tropical 44, 877-890.

Rojas, L.A. Chavarría, M.L, 2005. Corredores Biológicos de Costa Rica. Sistema Nacional de Áreas de Conservación, Corredor Biológico Mesoamericano, and Ministerio del Ambiente y Energia, published in collaboration with The Leatherback Trust, Wildlife Conservation Society, and Critical Ecosystem Partnership Fund, San José, Costa Rica, 216 pp.

Roldan, A.I., Simonetti, J.A., 2001. Plant-mammal interactions in tropical Bolivian forests with different hunting pressures. Conservation Biology 15, 617-623.

Sader, S.A., Joyce, A.T., 1988. Deforestation rates and trends in Costa Rica, 1940 to 1983. Biotropica 20, 11-19.

Sánchez-Azofeifa, G.A., Harriss, R.C., Skole, D.L., 2001. Deforestation in Costa Rica: quantitative analysis using remote sensing imagery. Biotropica 33, 378-384.

Sánchez-Azofeifa, G.A., Daily, G.C., Pfaff, A.S.P., Busch, C., 2003. Integrity and isolation of Costa Rica's national parks and biological reserves: examining the dynamics of land-cover change. Biological Conservation 109, 123-135.

Sherman, P.M., 2002. Effects of land crabs on seedling densities and distributions in a mainland Neotropical rain forest. Journal of Tropical Ecology 18, 67-89.

Simberloff, D., Farr, J.A., Cox, J., Mehlman, D.W., 1992. Movement corridors: conservation bargains or poor investments? Conservation Biology 6, 493-504.

SINAC [Sistema Nacional de Áreas de Conservación], 2008. Vida silvestre: Lista oficial de las especies de flora y fauna silvestre con poblaciones reducidas y en peligro de extinsión. www.sinac.go.cr/vidasilvestre.php. (Accessed 3.12.08).

Stevenson, P.R., 2000. Seed dispersal by wooly monkeys (Lagothrix lagothricha) at Tinigua National Park, Colombia: Dispersal distance, germination rates, and dispersal quantity. American Journal of Primatology 50, 275-289.

Stoner, K.E. Timm, R.M., 2004. Tropical dry-forest mammals of Palo Verde: ecology and conservation in a changing landscape. In: Frankie, G.W., Mata, A., Vinson, S.B. (Eds.), Biodiversity Conservation in Costa Rica: Learning the Lessons in Seasonal Dry Forest. University of California Press, Berkeley, pp. 48-66.

Stoner, K.E., Riba-Hernández, P., Vulinec, K., Lambert, J.E., 2007a. The role of mammals in creating and modifying seedshadows in tropical forests and some possible consequences of their elimination. Biotropica 39, 316-327. 
Stoner, K.E., Vulinec, K., Wright, S.J., Peres, C.A., 2007b. Hunting and plant community dynamics in tropical forests: a synthesis and future directions. Biotropica 39, 385-392.

Taber, A.B., Novaro, A.J., Neris, N., Colman, F.H., 1997. The food habits of sympatric jaguar and puma in the Paraguayan Chaco. Biotropica 29, 204-213.

Terborgh, J., 1992. Maintenance of diversity in tropical forests. Biotropica 24, 283292.

Tewksbury, J.J., et al., 2002. Corridors affect plants, animals, and their interactions in fragmented landscapes. Proceedings of the National Academy of Sciences 99, in fragmented $12923-12926$.

Timm, R.M., 1994. The mammal fauna. In: McDade, L.A., Bawa, K.S., Hespenheide, H.A., Hartshorn, G.S. (Eds.), La Selva: Ecology and Natural History of a Neotropical Rain Forest. University of Chicago Press, Chicago, 394-398, pp. 229tropical.

Timm, R.M., 2000. Prehistoric cultures and inhabitants. In: Nadkarni, N.M., Wheelwright, N.T. (Eds.), Monteverde: Ecology and Conservation of a Tropical Cloud Forest. Oxford University Press, New York, pp. 408-409.

Timm, R.M., LaVal, R.K., 2000. Mammals. In: Nadkarni, N.M., Wheelwright, N.T. (Eds.), Monteverde: Ecology and Conservation of a Tropical Cloud Forest. Oxford University Press, New York, 553-560, pp. 223-244.

Timm, R.M., McClearn, D.K., 2007. The bat fauna of Costa Rica's Reserva Natural Absoluta Cabo Blanco and its implications for bat conservation. In: Kelt, D.A.,
Lessa, E.P., Salazar-Bravo, J., Patton, J.L. (Eds.), The Quintessential Naturalist: Honoring the life and Legacy of Oliver P. Pearson, vol. 134. University of California Publications in Zoology, pp. 303-352.

Timm, R.M., Wilson, D.E., Clauson, B.L., LaVal, R.K., Vaughan, C.S., 1989. Mammals of the La Selva-Braulio Carrillo Complex, Costa Rica. North American Fauna 75, 1162.

Wallace, D.R., 1992. The Quetzal and the Macaw: The story of Costa Rica's National Parks. Sierra Club Books, San Francisco, 222 pp.

Weldon, A.J., 2006. How corridors reduce Indigo Bunting nest success. Conservation Biology 20, 1300-1305.

Wessberg, O., 1968. The story of El Cabo and an appeal and report from the sanctuary in Costa Rica. The Animals' Champion and the Way to Health 99 (162), 14-16.

Whitmore, T.M., Turner II, B.L., 1992. Landscapes of cultivation in Mesoamerica on the eve of the conquest. Annals of the Association of American Geographers 82, 402-425.

Wright, S.J., 2003. The myriad consequences of hunting for vertebrates and plants in tropical forests. Perspectives in Plant Ecology, Evolution and Systematics 6, 7386.

Wright, S.J., Zeballos, H., Domínguez, I., Gallardo, M.M., Moreno, M.C., Ibáñez, R., 1999. Poachers alter mammal abundance, seed dispersal, and seed predation in a Neotropical forest. Conservation Biology 14, 227-239. 